\title{
Two New Pollen Genera \\ (Late Cretaceous and \\ Paleocene) With Possible \\ Affinity to the Illiciaceae
}

GEOLOGICAL SURVEY PROFESSIONAL PAPER 643-F

Work done in cooperation with the

Kentucky Geological Survey

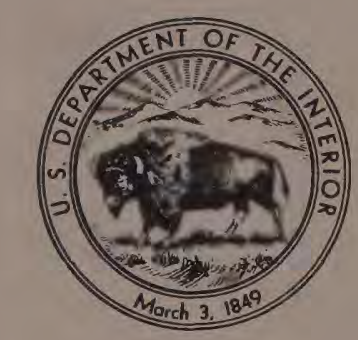




\section{Two New Pollen Genera}

(Late Cretaceous and

Paleocene) With Possible

Affinity to the Illiciaceae

By ROBERT H. TSCHUDY

C O NTR I B U T I ONSTO PALEONTOLOGY

GEOLOGICAL SURVEY PROFESIONAL PAPER 643-F

Work done in cooperation with the

Kentucky Geological Survey

Two new genera Terscissus and Trisectoris

are described, and the stratigraphic ranges

of the species are delineated

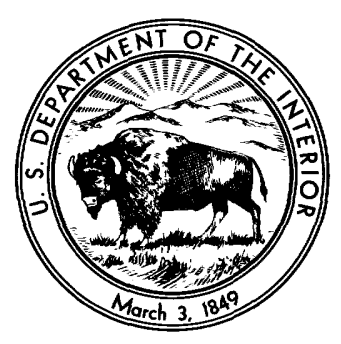

UNITED STATES GOVERNMENT PRINTING OFFICE, WASHINGTON : 1970 


\section{UNITED STATES DEPARTMENT OF THE INTERIOR}

WALTER J. HICKEL, Secretary

\section{GEOLOGIGAL SURVEY}

William T. Pecora, Director

For sale by the Superintendent of Documents, U.S. Government Printing Office Washington, D.C. 20402 - Price 50 cents (paper cover) 


\section{CONTENTS}

Abstract

Introduction.

Acknowledgments Source of material

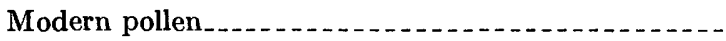

Fossil pollen localities.

The modern genus Illicium. Systematic descriptions.

Genus Terscissus n. gen

Terscissus grandis n. sp......................

Terscissus canalis n. sp. . . . .

Terscissus crassus n. sp.....................

Terscissus sp. 1 .

Terscissus sp. 2_._.

Terscissus sp. 3

Terscissus sp. 4

\begin{tabular}{r|} 
Page \\
F1 \\
1 \\
1 \\
2 \\
2 \\
2 \\
2 \\
4 \\
5 \\
5 \\
5 \\
6 \\
6 \\
7 \\
7 \\
8 \\
8 \\
8
\end{tabular}

Systematic descriptions-Continued

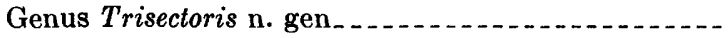

Trisectoris costatus n. $\mathrm{sp}$

Trisectoris stoveri $\mathrm{n} . \mathrm{sp}_{\mathrm{H}}$

Trisectoris sp. 1._._.

Trisectoris sp. 2

Morphologic synopsis of the genera Illicium, Terscissus, and Trisectoris_.........

Other possibly related genera

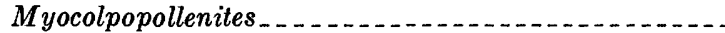
Tricolpites ........... Stratigraphic distribution of the genera Terscissus and Trisectoris . .

The genus Terscissus............

The genus Trisectoris........

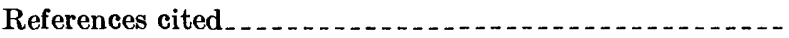

Fage

F8

8

9

9

9

10

10

10

10

11

11

13

\section{ILLUSTRATIONS}

[Plates follow index]

Plate 1. Modern Illicium species.

2. Terscissus grandis holotype and paratypes.

3. Terscissus grandis isolated segments.

4. Terscissus canalis holotype and paratypes.

5. Terscissus crassus holotype and paratypes.

6. Reticulate species of Terscissus.

7. Terscissus species 4 and Trisectoris costatus holotype and paratypes.

8. Trisectoris stoveri holotype and paratypes and other species of Trisectoris.

9. Myocolpopollenites and Tricolpites.

Figure 1. Index map of fossil localities in Maryland and New Jersey, the Mississippi embayment region, northern New Mexico, and western Venezuela.

2. Stratigraphic ranges of species of the genera Terscissus and Trisectoris.

\section{TABLE}

$\mathrm{T}_{\mathrm{ABLE}}$ 1. Comparison of some morphologic features of the genera Illicium, Terscissus, and Trisectoris 


\title{
TWO NEW POLLEN GENERA (LATE GRETACEOUS AND PALEOGENE) WITH POSSIBLE AFFINITY TO THE ILLICIACEAE
}

\author{
By RoBert H. Tschudy
}

\begin{abstract}
Palynological examination of Upper Cretaceous and Paleocene samples disclosed several pollen species that are commonly found as isolated thirds, rather than complete specimens. Two new fossil pollen genera, Tersoissus and Trisectoris, are described for these pollen species. Three new species are included in the genus Terscissus and two new species are assigned to the genus Trisectoris. Four unnamed species belonging to the genus Terscissus and two to the genus Trisectoris are discussed and figured. Comparison is made with some species of the modern genus Illicium, which also possess the tendency to separate into three isolated segments.

All the species in these two genera are from rocks of Late Cretaceous and Paleocene age. The stratigraphic range of each species is shown.
\end{abstract}

\section{INTRODUCTION}

During the investigation of Cretaceous and Tertiary pollen and spore assemblages from the Mississippi embayment region, several species of morphologically distinctive palynomorphs were noted from samples immediately above and below the Cretaceous-Tertiary boundary. Much later, the discovery of complete specimens proved that these distinctive palynomorphs were, in fact, separate thirds of pollen grains. The discovery of complete grains reminded me that $I$ had found similar-appearing forms while examining samples from Venezuela. A reexamination of the Venezuelan material confirmed that some of the Venezuelan fossils closely resembled one of the species from the Mississippi embayment region.

A comparison of these new fossil pollen grains with grains of modern pollen led to the conclusion that the morphologic features of the fossils most closely resembled some features of pollen grains of the modern genus Illicium in the Illiciaceae. Illicium is a member of the most primitive order of angiosperms, the Ranales (Stebbins, 1950, p. 471).

The principal feature shared by modern pollen of some species of Illicium and the fossil pollen described below is the tendency to split into thirds along the syncolpate suture lines. I know of no other genus of modern plants in which this occurs.

The modern genus I77icium includes species with two different types of pollen, the syncolpate type with colpi bordered by ridges or thickenings (margos) and the tricolpate type, morphologically almost identical vith the syncolpate type, in which the colpi do not quite reach the poles. The pollen grains of Schizandra and Kadsura, also belonging to the Ranales, though not syncolpate, are somewhat similar morphologically to the pollen of Illicium, but Illicium is unique in the possession of syncolpate pollen grains that split into thirds.

Two new genera have been erected to accommodate the new species described in this paper. These species are useful fossils of comparatively narrow stratigraphic range.

\section{ACKNOWLEDGMENTS}

I wish to thank Mr. R. A. J. Rosset of Compañia Shell de Venezuela, Ltd., Mr. J. A. Shields of Mobil Oil Company de Venezuela, Mr. Amos Salvador, and Mr. Virgil Winkler of Creole Petroleum Corporation of Venezuela for giving me permission to publish data pertaining to the fossils from Venezuelan rocks. I am grateful to Mr. W. W. Fairchild, Standard Oil of Texas, for providing the sample from the Bayou Jennan Member of the Pendleton Formation of the Wilcox Group. Jack A. Wolfe generously allowed me to use some of his specimens from the Magothy Formation. I thank also Mr. Richard H. Eyde of the Smithsonian Institution, Washington, D.C., for supplying polleniferous material of three species of modern Illicium, and Avalonne Kosanke and the Denver Botanic Gardens for providing flowers of Illicium anisatum. Sharon Van Loenen and Helen Pakiser were of inestimable hel? in preparing the material and photographing the fossils. 


\section{METHODS OF PROCESSING SAMPLES AND PREPARING SLIDES}

Rock samples were treated in a conventional manner by use of hydrofluoric acid to disaggregate and partly dissolve the inorganic matrix. The residue was then oxidized with Schulze solution $\left(\mathrm{HNO}_{3}+\mathrm{NaClO}_{3}\right)$, and the solubilized humates were removed by a short exposure to 10-percent NaOH solution. Pollen and spores were concentrated from the residue by flotation by use of zinc bromide (specific gravity about 2) and were then "panned" by means of the technique suggested by Funkhouser and Evitt (1959).

In most of the preparations the palynomorphs were mixed with Vinylite AYAF in 90-percent alcohol (polyvinyl acetate plastic, refractive index 1.466). Several drops of the mixture were placed on a cover glass, and another cover glass placed on the mixture thus forming a sandwich. After the plastic had spread evenly to the margins, the cover glasses were separated by sliding them in opposite directions lengthwise in much the same manner as a blood smear is made. This method provided a thin, evenly distributed film of pollen and spores in a mountant of favorable refractive index. After the mixture on the cover glasses had dried for a few minutes on a warming plate, the cover glasses were inverted and mounted on slides in Permount. This method serves to anchor all the fossils close to the cover glass so that they can be examined conveniently, even under high-power oil-immersion lenses. The use of Vinylite was suggested by Alfred Traverse (written commun., 1958). Some of the preparations were mounted in canada balsam, and a few of the earlier preparations of Venezuelan material were mounted in glycerine jelly.

\section{SOURCE OF MATERIAL}

\section{MODERN POLLEN}

The photographs of modern Illicium pollen included in this report are of pollen from permanent slides on file in the palynological laboratory of the U.S. Geological Survey in Denver, Colo. For the most part the modern pollen was obtained from flowers on herbarium sheets. Anthers from these flowers were acetylated by means of Erdtman's (1943) method to remove cellulosic tissue and the cell contents of the pollen grains. The pollen was then mounted on slides in AYAF plastic, as outlined above. Each preparation was given an accession number with the prefix $\mathrm{P}$; for example, P2855 Illicium floridanum Ellis. This number is referred in the accession book to the herbarium sheet from which it was obtained. Multiple slides from the same preparation are indicated thus: P2855, slide 1; P2855, slide 3.

\section{FOSSIL POLLEN LOCALITIES}

The fossil pollen grains from the United States used in this study are cataloged under the appropriate U.S. Geological Survey locality and slide numbers; for example, D3000, slide 7. Those from Venezuela are listed under preparation and slide numbers; for example, TS-200, slide 3.

The rock samples that yielded specimens of the new genera Terscissus and Trisectoris are from four general localities : The Mississippi embayment region, the coastal plain of Maryland and New Jersey, northern New Mexico, and western Venezuela (fig. 1). Specimens used in this study, including those shown on th plates, are from the following specific localities.

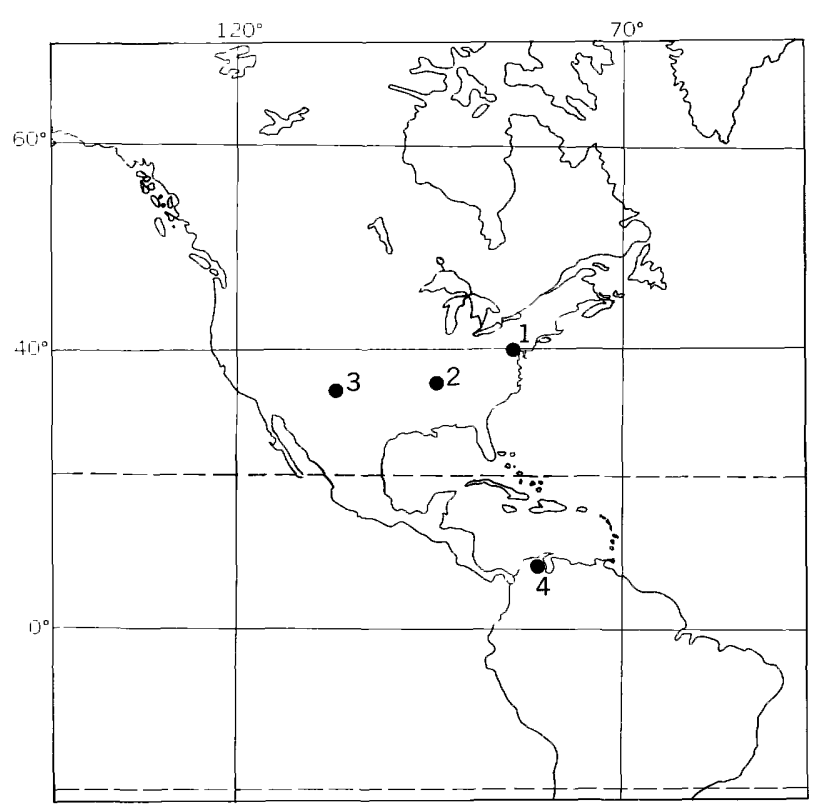

Figure 1.-Fossil localities in Maryland and New Jersey (1), the Mississippi embayment region ( $\approx$ ), northern New Mexico (3), and western Venezuela (4).

\section{United States}

specimens:

USGS

paleobotany

loc. Nos.

Locality

D1322_._. - Type locality. 2.25 miles $\mathrm{S}$. of Lakeshore, Md., on North Ferry Point, adjacent to and on N. bank of Magothy River, Anne Arundel County, Md.

D1846_... Type locality of Bayou Lennan Member. NW1/4SW1/4 sec. 12 , T. 6 N., R. 13 W., Sabine Parish, La. Elev $165 \mathrm{ft}$ (Andersen, 1960, p. 75).

\author{
Stratigraphic unit \\ Magothy For- \\ mation. \\ Bayou Lennan \\ Member, Pen- \\ dleton For- \\ mation of An- \\ dersen (1960) \\ in Wilcox \\ Group.
}


United States specimens: paleobotany loc. Nos.

D1864. Iocality

On abandoned lane $900 \mathrm{ft} \mathrm{S}$. of Independence School; Kentucky coordinates, South zone, E. 1,267,650 ft; N. 144,650 ft, Hico 71/2-min quad., Calloway County, Ky.

D1867 _... 1, 1,000 ft SE. of Independence School; eastward cut in right wall of stream; Kentucky coordinates, South zone, E. $1,268,500 \mathrm{ft}$; N. $145,000 \mathrm{ft}$, Hico $71 / 2$-min quad., Calloway County, Ky.

D1967-A_ - Type locality of MeNairy Sand Member. W. end of big cut in Southern RR. E. of Dismal Swamp and Tuscumbia River. Base is approximately same elevation as track and $40 \mathrm{ft} \mathrm{NW}$. of railroad crossing. South center NW1/4 SW1/4, Chewala quad., MeNairy County, Tenn.

D3000_... 1,850 ft ENE. of Roberts cemetery, 2.1 miles ESE. of Shiloh, stream channel of headwater drainage of Sugar Creek; Kentucky coordinates, South zone, E. 1,289,050 ft; N. 135,150 ft, Hico 71/2-min quad., Calloway County, Ky.

D3001 $6,500 \mathrm{ft} \mathrm{SSW}$. of Shiloh in channel of tributary of Jonathan Creek; Kentucky coordinates, South zone, E. $1,272,250 \mathrm{ft}$; N. $132,050 \mathrm{ft}$, Hico 73:-min quad., Calloway County, $\mathrm{Ky}$.

D3143-B _ - Right bank of Clarks River, 0.25 mile W. of Cold Spring; Kentucky coordinates, South zone, E. 1,186,550 ft; N. $251,450 \mathrm{ft}$, Symsonia quad., McCracken County, Ky.

D3210_...- N. side of Ohio River near water MeNairy Sand. level (elev $291.5 \mathrm{ft}$ ); about $1,000 \mathrm{ft}$ downstream from statue in Massac Park; Kentucky coordinates, South zone, E. 1,135,800 ft; N. $307,700 \mathrm{ft}$, Metropolis quad., Massac County, Ill.

D3378... - . Drill hole PW-14 in Noble Park, Kentucky coordinates, South zone, E. 1,158,150 ft; N. 287,700 ft, Paducah West 71/2-min quad., McCracken County, Ky.
Stratigraphic unit

McNairy Sand.

Clayton Formation.

\section{MeNairy Sand Member of Ripley} Formation.

MeNairy Sand.

McNairy Sand.

\section{Clayton For- mation.}

MeNairy Sand.

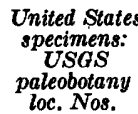

Locality

Stratigraphic unit

D3410

Type locality. From right bank of Owl Creek, 2.5 miles NE. of Ripley, Miss., E广⿳2 sec. 7, T. 4 S., R. 4 E., Tippah

County, Miss.

D3410-B _ $14 \mathrm{ft}$ above stream level

D3410-C_ _ $22 \mathrm{ft}$ above stream level_........ Owl Creek

D3412_... - Type locality, near middle. Elev $440 \mathrm{ft}$ along bluff on left bank Tennessee River 0.3 mile downstream from mile 185 and 0.9 mile $\mathrm{E}$. of crossroads N. of Coffee Landing, Hardin County, Tenn.

D3416_..._ $6 \mathrm{ft}$ below unconformable contact with Owl Creek Formation; NW1/4NW1/4 sec. 10 , T. 27 N., R. 11 E., Advance $7 \frac{1}{2}$ min quad., Stoddard County, Mo.

D3420_-_. 1.15 miles NNE. of Thomson Chapel; $550 \mathrm{ft} \mathrm{N}$., $75 \mathrm{ft} \mathrm{E}$. of road junction E. side of U.S. Highway $60 ; 0.9$ mile $\mathrm{S}$. of $\mathrm{N}$. edge Little Cypress 71/2-min quad.; Kentucky coordinates, South zone, E. 1,227,200 ft; N. 292,400 ft, Livingston County, Ky.

D3507_... 0.5 mile S. of Reidland High School, elev $320 \mathrm{ft}$; small tributary of Clarks River; Kentucky coordinates, South zone, E. 1,186,500 ft; $N$. 258,300 ft, Paducah East 71:-min quad., McCracken County, $\mathrm{Ky}$.

D3522_... $600 \mathrm{ft}$ SE. Independence School; McNairy Sand. Kentucky coordinates, South zone, E. $1,268,350 \mathrm{ft}$; N. $145,100 \mathrm{ft}$, Hico $71 \frac{1}{2}$-min quad., Calloway County, $\mathrm{Ky}$.

D3522-A_ - 4-5 ft below stream MeNairy Sand. D3523_.._ 0.9 mile SW. of Shiloh, elev 145 McNairy Sand. ft; Kentucky coordinates, South zone, E. 1,272,900 ft; N. 136,600 ft, Hico 71/2-min quad., Calloway County, Ky.

D3524_._. 0.75 mile SW. of Shiloh, elev 125-130 ft; Kentucky coordinates, South zone, $\mathbf{E}$ $1,275,650 \mathrm{ft}$; N. $134,100 \mathrm{ft}$, Hico $7 \frac{1}{2}$-min quad., Calloway County, Ky.
Upper part, MeNairy Sand.

McNairy Sanc'.
MeNairy Sand.
Clayton For-
mation.

Clayton For-
mation.

\author{
Owl Creek \\ Formation. \\ Formatlon. \\ owl Creek \\ Formation. \\ Coffee Sand.
}




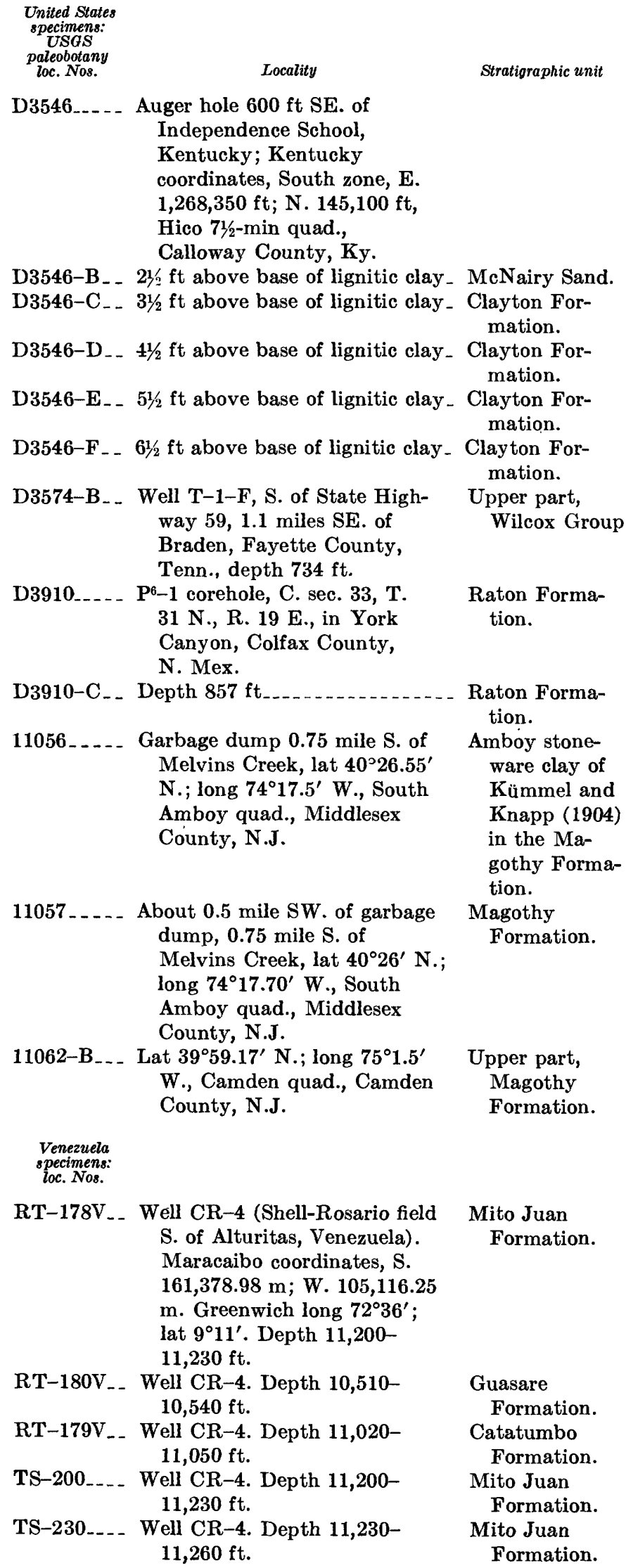

\section{Raton Forma-} tion.

Amboy stoneware clay of Kümmel and Knapp (1904) in the Magothy Formation.

Magothy Formation.

Upper part, Magothy Formation.

Mito Juan Formation.

Guasare Formation. Catatumbo Formation. Mito Juan Formation. Mito Juan Formation.

Venezuela specimens:
loc. Nos.

Z390V

Locality

Rosalia 1 well (Mobil wildcat in Barinas near Apure River, Venezuela). Maracaibo coordinates, S. $332,367.44 \mathrm{~m}$; E. 116,781.00 m. Greenwich lat $7^{\circ} 39^{\prime}$; long $70^{\circ} 34^{\prime}$. Depth 9,260-9,270 ft.

\section{THE MODERN GENUS ILLICIU:}

Illicium is a genus of aromatic shrubs or sinall trees. With the exception of several species found in Southern United States, its distribution is primarily confined to Southeast Asia (Japan, Malaysia, Philippine Republic, China, and India). About 20 species were attributed to the genus by Wodehouse (1935). As many as 42 species were placed in the genus by A. C. Smith (1947). Pollen grains of all species heretofore reported are from $28 \mu$ (microns) to $35 \mu$ in diameter. Descriptions of the pollen of only four species are available to me. The descriptions are included here.

Illicium floridanum Ellis

Illustrated specimens from colln. W. H. Duncan USNH 14879, Geneva County, Ala., March 29, 1953. Modern pollen preparation P2855. Plate 1, figures $1-4$.

Pollen described by Wodehouse (1935), Pokrovskaia (1950), and Erdtman (1952). Following description from Wodehorse (1935, p. $335)$ : "Grains uniform, spheroidel, about $28.5 \mu$ in diameter; tricolpate, occasionally dicolpate. Furrows long and slender, meeting at both poles, without germ pores. Exine completely covered by $\dot{a}$ system of anastomosing ridges bounding angular lacunae and ending with closed and somewhat smaller lacunae along the furrows, the ridges coalescing to form a sort of rim; mesh of the reticulum somewhat finer than in the grains of Drimys winteri, otherwise similar."

Remarks.-Pokrovskaia (1950) listed the size range as $21 \mu-30 \mu$. Pollen of this species is syncolpate.

Illicium religiosum (I. anisatum $\left(\mathrm{I}_{\Lambda_{0}}\right)$ Sieb. and Zucc.) Shikimi

Pollen described by Wodehouse (1935) and Pokrovskaia (1950). Following description from Wodehouse (1935, p. 336): "Grains indistinguishable from those of the preceding species. [I. floridanum]."

Remarks.-Pokrovskaia gave the size range as $24 \mu$ to $30 \mu$ and mentioned that the lacunae of the reticulum are smaller in I. religiosum than in I. floridanum. 
Illicium yunnanense Franchet

The following description from Wodehouse (1935, p. 336) : "Grains uniform, oblately flattened and more or less three-lobed in outline, about $30.8 \mu$ in diameter, tricolpate, with furrows long and tapering but not quite meeting at either pole, deeply sunken, imparting to the grain its three-lobed appearance. Furrow membrane marked with median linear thickenings throughout their length but with no indication of germ pores. Exine of the general surface uniformly reticulate, similar to that of grains of Schizandra. (pl. 5, fig. 10) but of heavier ridges and smaller and less angular lacunae."

Remarks.-All the species of Illicium that I have examined possess the median linear thickening throughout the lengths of the colpi. This feature is not present in the new fossil genera discussed in this report.

\section{Illicium anisatum Linn}

Illustrated specimens Colln. Avalonne Kosanke, from the Denver Botanic Gardens. Modern pollen preparation P3382. Plate 1, figures 13-17.

Following description from Erdtman (1952, p. 254): "Grains 3-colp (oid) ate [longicolp(oid) ate], suboblate (about $29 \times 35 \mu$ ). Sexine reticulate (or provided with an undulating tegillum?). Muri cf. dupli-tribaculate, carinate."

Remarks.-The specimen (pl. 1, figs. 13 and 14) shows the presence of the median linear colpal thickenings in polar view.

Pollen from two additional species of Illicium was obtained from flowers supplied through the courtesy of Mr. Eyde of the Smithsonian Institution. Descriptions of these species follow:

Illicium simonsii Maxim

Colln. J. F. Rork USNH 11725 Yunan (China), March 1924. Modern pollen preparation P2856. Plate 1, figures 9-12.

Grains spheroidal, often slightly prolate, $31 \mu-36 \mu$ in diameter; tricolpate. Colpi long and slender, approaching but not meeting at either pole. Colpi membranes possessing median linear thickenings throughout their entire length. Exine coarsely reticulate, lacunae distinctly larger in the equatorial region than at the poles and along the colpi, muri coarse, duplibaculate to multibaculate. Colpi bordered by thickened exine made up of anastomosed muri. Separate segments (thirds) rarely found after acetylation.

Illicium henryi Diels var. typicum A. C. Smith

Colln. E. H. Wilson USNH 3087 Hupeh
(China). Modern pollen preparation $\mathrm{P} 2{ }^{\mathrm{5}} 57$. Plate 1, figures 5-8.

Grains spheroidal, $28 \mu-34 \mu$ in diameter, syncolpate, colpi long and slender, meeting at both poles. Colpal membranes with median linear thickenings. Exine uniformly reticulate except along the colpi, lacunae irregular in outline, muri narrow, similar to those in $I$. anisatum. Separate segments (thirds) common after acetylation.

Remarks.-The separation of pollen grains of Illicium into segments is mentioned by Pokrovslaia (1950): "The exine [of Illicium] of the furrows is thin. Also, as a result of alkali treatment, the membrana of the furrows splits easily in such a manner that the pollen is found divided into three parts in the form of snlit sections of an orange, whenever the furrows approach the poles."

\section{THE NEW FOSSIL GENERA, TERSCISSUS AND TRISECTORIS}

All photographed specimens of fossils recorled herem are on slides deposited in the palynological laboratory of the U.S. Geological Survey in Denver, Colo. All illustrated specimens are within black-ink circles marked directly on the slides; they may also be located on the slides by mechanical-stage coordinates given in the plate explanations. In order that others may convert their mechanical-stage readings to those recorded for the specimens included in this report, the coordinates for the center point of a $1 \times 3$-inch standard microscope slide are 108.0 and $12.3 \mathrm{~mm}$. The method of accurately locating the center of a standard microscope slide is described by Tschudy (1966, p. D78). With the slide label to the left, our vertical coordinates decrsase toward the near edge of the slide and the horizontal coordinates decrease toward the right-hand end of the slide.

In addition to slides of the illustrated specimons, color photographs of the new genera and species described in this report are available from the U.S. Geological Survey laboratory, Denver, Colo., on a limited-time loan basis.

\section{SYSTEMATIC DESCRIPTIONS}

Genus TERSCISSUS n. gen.

Type species.-Terscissus grandis $\mathrm{n}$. sp.

Diagnosis.-Pollen grains radially symmetrical; outline circular, rounded triangular or slightly three lobed; inaperturate, syncolpate, or syncolpoidate; divided into three segments by prominent grovves (colpi) bordered by prominent margos or lips, grooves joining at both poles. Complete grains usually rare, 
more often occurring as isolated thirds. Ornamentation various, reticulate, clavate, or baculate.

\section{Terscissus grandis n. sp.}

Plate 2, figures 1-4 ; plate 3, figures 1-6

Holotype.-D3546-C, slide 5, coordinates $98.0 \times$ 11.5 , plate 2 , figures 1,2 .

Paratype.-D3546-C, slide 5, coordinates $88.3 \times$ 21.3, plate 2, figure 3 .

Paratype.-D1867, slide 8, coordinates $91.3 \times 18.3$, plate 2, figure 4.

Diagnosis.-Large syncolpate pollen grains, with prominent margos; surface ornamentation of regularly distributed islands made up of several clavae fused at their tips; areas devoid of clavae with short, densely packed verrucae.

Description.-Complete specimens are rounded triangular to slightly trilobed in outline. Based on 20 complete specimens and over 100 isolated segments, the diameter has been determined to range from $125 \mu$ to $185 \mu$. Dimensions of isolated thirds are $58 \mu \times 78 \mu$ (lateral) and $106 \mu \times 124 \mu$ (radial). Three colpi, extending from pole to pole (syncolpate), divide the surface into three well-defined areas. Commonly the fossils are found as isolated segments or thirds, which indicate that the colpus or furrow membranes are thinner than the remainder of the exine. The colpi are bordered by prominent margos, which are separated from the remainder of the surface by thinner areas or channels. The wall is $12 \mu-18 \mu$ thick, including the sculpture. The endexine is $3 \mu-5 \mu$ thick. The clavae of the ektexine are about $8 \mu-13 \mu$ long and irregularly fused at their tips forming an incomplete tectum. Areas devoid of clavae and, in particular, areas in channels separating the margos from the remainder of the heavily sculptured areas possess short, densely packed verrucae.

Discussion.-The shape of isolated segments is roughly deltoid in polar view and circular where found in equatorial view. Several isolated segments are shown on plate 3 (figs. 2-5). Such segments are much more common in palynological preparations than are complete specimens. Interference contrast photographs (pl. 3 , fig. 1) provide a view of the surface relief and clearly show the small verrucae at the base of the larger sculptural elements and in the channels adjacent to the prominent margos.

Sparse broken pieces of the margos are found (pl. 3 , fig. 6). These provide excellent sections of the wall in the vicinity of the colpi and show the apical fusion of the large clavae.

All specimens from the Owl Creek Formation appear to differ from specimens from the Clayton Formation by possessing slightly larger clavae. Some clavae are fused at their apices to form an incomplete tectum (pl. 3, figs. 4, 5). Some Owl Creek specimens display a tendency to have an incomplete banding arrangement of the coarse sculptural elements centrifugal to the channel which separates the margo from the remainder of the surface. This tendency is not apyarent in all specimens. Because of the absence of complete specimens from the Owl Creek and the fact that all Owl Creek specimens do not show the tendency to banding, it seems inappropriate at this time to erect a new species for Owl Creek specimens on the basis of the slightly larger size of the surface clavae-the only feature that differentiates these forms from T'erscissus grandis.

Affinity.-A similarity to the modern gonus Illicium is suggested by the gross morphology of the pollen grains and the tendency of the grains to split into thirds. The fossils assigned to Terscissus grandis, however, are many times larger than pollen cf any known species of modern Illicium. Affinity with the Illiciaceae is postulated.

Occurrence.-Terscissus grandis has been found in the Clayton Formation of Paleocene age. One specimen was found in the upper part of the Upper Cretaceous McNairy Sand, and many specimens of a slightly variant form were found in the Owl Creek Formation of Late Cretaceous age. All these rocks are present in the upper part of the Mississippi embayment region.

Terscissus canalis n. sp.

Plate 4, figures 1-6

Holotype.-RT-178V, slide alpha, coordinates 106.3 $\times 7.9$, plate 4, figure 1 .

Paratype.-RT-178V, slide alpha, coordinates 95.0 $\times 13.0$, plate 4, figure 2 .

Paratype.-RT-178V, slide alpha, coordinates 107.0 $\times 19.4$, plate 4 , figure 3 .

Paratype.-RT-178V, slide beta, coordinates 97.2 $\times 15.1$, plate 4 , figure 4 .

Diagnosis.-Large syncolpate pollen grains, with prominent margos; each third with three channels separating the densely packed clavae into a margo, two annular segments, and one circular segment.

Description.-Complete specimens are probably rounded triangular to slightly trilobed in outline. The one complete specimen is distorted. The dimensions of the one complete specimen are $140 \mu \times 184 \mu$. On the basis of 20 isolated segments (thirds), the dimensions of the segments have been determined to range from $74 \mu$ to $160 \mu$ (lateral) and $80 \mu$ to $100 \mu$ (radial). Three colpi, extending from pole to pole (syncolpate), divide the surface into three well-defined areas. The membranes of the colpi or furrows are relatively thin, per- 
mitting easy separation of the pollen grain into three segments. The colpi are bordered by prominent margos or lips. The margo is separated from the remainder of the heavily sculptured surface by a narrow channel. Two additional continuous channels divide each segment into three annular bands plus a circular central portion. The wall is $11 \mu-18 \mu$ thick, including the sculpture. The endexine is $3 \mu-5 \mu$ thick and the ektexine ranges in thickness from $8 \mu$ to $14 \mu$. The surface, except in the channels, is densely covered with robust clavae; some clavae are fused at their tips with adjacent clavae. Short verrucae or granulae are present in the floor of the channels but are difficult to see except in abnormally expanded specimens. This species differs from Terscissus grandis by possessing a wall separated into annual segments, by the much greater density of the large surface clavae, and by the lack of readily visible verrucae between the large clavae.

Discussion.-The shape of isolated segments is identical with that of segments of Terscissus grandis. Because only one complete specimen was found and because the species can easily be identified from isolated thirds, isolated thirds were chosen as paratypes. One of the paratypes shown (pl. 4, fig. 3) lacks the margo but is otherwise a complete segment. As in the type species, isolated fragments only of the margo are found. One of these fragments, which provides a cross section of the wall of the margo, is shown on plate 4 , figure 6 . The thick endexine and the clavae whose enlarged tips are fused into a tectum are shown. The tightly packed clavae and the surface relief are seen in another picture (pl. 4, fig. 5) taken using interference contrast.

Affinity.-Possibly with the Illiciaceae.

Occurrence.-This species has so far been found only in the Mito Juan Formation of Maestrichtian age in western Venezuela.

\section{Terscissus crassus n. sp.}

Plate 5, figures 1-6

Holotype.-RT-179V, slide 6 , coordinates $90.0 \times$ 16.9, plate 5, figure 1 .

Paratype.-RT-179V, slide 8, coordinates $94.8 \times$ 13.7, plate 5, figure 2 .

Paratype.-RT-179V, slide 10, coordinates $105.2 \times$ 19.3, plate 5 , figure 3 .

Paratype.-RT-179V, slide 10 , coordinates $88.4 \times$ 9.4, plate 5 , figure 4.

Paratype.-RT-179V, slide 9 (single grain), coordinates $105.0 \times 12.0$, plate 5 , figure 5 .

Diagnosis.-Large syncolpate pollen grains with prominent margos; coarse clavae mushroom shaped and a few fused with adjacent clavae at their tips; no visible verrucae between large clavae.
Description.-No complete grains were found. On the basis of 33 segments and many fragments, the dimonsions of the individual thirds have been determined to range from $90 \mu$ to $100 \mu$ (lateral) and $120 \mu$ to $140 \mu$ (radial). The holotype, though broken and incomplete, shows clearly the three-segment characteristic of the genus. Three colpi, extending from pole to pole (s:ncolpate), divide the grains into three well-defined areas. The colpi or furrow membranes are thinner than the remainder of the exine, facilitating the separation of the segments. The colpi are bordered by very prominent margos. The wall is $10 \mu-16 \mu$ thick, including the sculpture. The endexine is $3 \mu-5 \mu$ thick. Clavae are $7 \mu-11 \mu$ long, enlarged, mushroom shaped at the tips, and often fused at the tips with one to several adjacent clarae. Clavae are robust and densely packed, thus giving the appearance of a coarsely verrucate surface. Some specimens have a tendency toward channeling and annular arrangement of fused clavae. This species differs from $T$. grandis and $T$. canalis by having coarser, more densely packed structural elements in the ektexine and by lacking visible small verrucae between the cosrse clavae.

Discussion.-The colpal margos of this species, Jike those of $T$. canalis and $T$. grandis, are made up of fured clavae. The fusion is such that the margos are noticeably smoother than the margos of the previously described species. The mushroom shape of the clavae can be seen on the specimen on plate 5 , figure 3 . Two adjacent fured clavae are shown on plate 5 , figure 4 .

Affinity.-Possibly with the Illiciaceae.

Occurrence.-This species has been found only in the Catatumbo Formation of early Paleocene age in western Venezuela.

Other Terscissus species.-During the examination of Venezuelan samples, several additional species were found. All of these are characterized by a reticulate sculpture. Sufficient specimens to adequately circumscribe these species were not available. Consequently, these species have not been given specific epithets. $T$. $y$ are included here as records of additional members of the genus Terscissus.

\section{Terscissus sp. 1}

Plate 6, figures 1, 2

Discussion.-This species possesses such prominent and distinctive morphology that it cannot be confused with any other taxon. Only one complete specimen and one isolated segment were found. The complete specimen is rounded triangular to slightly trilobed in outline (polar view). Three colpi join at the poles to form a syncolpate grain. The colpi are bordered by margos, and the endexine is thickened adjacent to the colpi. This 
thickening is shown on plate 6 , figure 1 , on the part of the grain from which the reticulate ektexine has been removed. The wall is $16 \mu-19 \mu$ thick, including the sculpture. The endexine is $3 \mu-5 \mu$ thick, except along the margins of the colpi where it is thicker. The ektexine is made up of pillars $3 \mu-5 \mu$ in diameter and $6 \mu-10 \mu$ long that support a coarse reticulum made up of cylindrical elements $3 \mu-4 \mu$ in diameter. The reticulum in surface view is vermiculate; the endexine surface is granulate.

The specimen photographed (pl. 6, fig. 1) has had the reticulate tectum removed from part of the surface, thus clarifying the structure of the ektexine. The isolated segment (third) on plate 6, figure 2 , shows clearly the irregular nature of the lacunae of the reticulum.

Affinity.-Possibly with the Illiciaceae.

Occurrence.-This species has been found only in the Guasare Formation of Paleocene age of western Venezuela.

\section{Terscissus sp. 2}

Plate 6, figures 3-6

Discussion.--Two specimens (thirds) whose morphology appears very similar to that of $T$. sp. 1 were found. These specimens are distinctly smaller, and the elements of the reticulum are smaller, than those in $T$. sp. 1 . A vermiculate irregular reticulum supported by comparatively robust pillars is present in this species also (pl. 6, fig. 4). This same specimen shows the torn inner thickening of the endexine along the colpi. It is postulated that this condition is approximated in $T$. sp. 1 .

Affinity.-Possibly with the Illiciaceae.

Occurrence.-These specimens are from the Upper Cretaceous Mito Juan Formation of western Venezuela.

Terscissus sp. 3

Plate 6, figures 7-9

Discussion.-Several specimens (thirds) of this species were found. The general morphology is similar to that of $T$. sp. 1 and $T$. sp. 2. This species is distinguished by a more regular reticulum and a reticulum whose lacunae are more numerous and smaller.

Affinity.-Possibly with the Illiciaceae.

Occurrence.-These specimens are from the Upper Cretaceous Mito Juan Formation of western Venezuela.

Terscissus sp. 4

Plate 7, figures 1, 2

Discussion.-A single complete specimen was found. It is rounded triangular in polar view and has a dense reticulum of fairly heavy muri and smaller irregular lacunae. It has prominent thickened margos adjacent to the colpi. The colpi extend from pole to pole, forming a syncolpate grain. The wall is about $8 \mu$ thick- $(16 \mu$ thick along the colpi).

Affinity.-Possibly with the Illiciaceae.

Occurrence.-This specimen is from the Catatumbo Formation of early Paleocene age of westerr Venezuela.

Genus TRISECTORIS n. gen.

Type species.-Trisectoris costatus $\mathrm{n}$. $\mathrm{sp}$.

Diagnosis. Pollen grains spherical or nearly so; syncolpate or syncolpoidate; divided into three segments that commonly separate; complete grains rare; ektexine of prominent longitudinal costae; costae seprated from endexine by prominent baculae.

\section{Trisectoris costatus n. sp.}

Plate 7 , figures $3-14$

Holotype.-D3001, slide 1, coordinates $83.3 \times 7.6$, plate 7 , figure 3.

Paratype.-D3001, slide 3, coordinates $82.0 \times 20.7$, plate 7 , figure 4 .

Paratype.-D1867, slide 1, coordinates $96.5 \times 18.8$, plate 7, figures 5,6 .

Paratype.-D1967-A, slide 2, coordinates $92.7 \times 2.4$, plate 7 , figures 7,8 .

Paratype.-D1864, slide 5, coordinates $76.4 \times 4.5$, plate 7, figures 9,10 .

Diagnosis.-Syncolpate pollen grains with prominent longitudinal costae that extend from pole to pole.

Discription.-Pollen grains spherical or spheroidal and syncolpate. On the basis of 12 complete specimens and over 100 isolated thirds, the diameter has been determined to range from $32 \mu$ to $49 \mu$. Dimensions of isolated thirds range from $21 \mu$ to $28 \mu$ (polar) and $31 \mu$ to $37 \mu$ (lateral). After separation the thirds con monly contract in their polar axis, forming distinctly cupped segments. Longitudinal costae range in number from 7 to 12 per segment. Costae adjacent to the colpi are continuous over the poles, thus forming a complete circle. Individual costae are $2 \mu-4 \mu$ wide equatorially, tapering toward the poles where they tend to fuse with adjacent costae. Costae are subtended on their inner face by \pm two rows of prominent baculae. In equatorial view baculae are easily seen through the costae. Jkktexine including baculae is $3 \mu-5 \mu$ thick, and baculae are as much as $2 \mu$ long. The endexine is very thin, about $1 \mu$ thick, and membranous. The costae and attached baculae are easily separable from the endexine.

Discussion.--Isolated thirds of Trisectoris costatus are shown on plate 7, figures 7-14. In figures 7 and 9, the supporting baculae are clearly shown. An enlarged view of a broken segment showing comblike "teeth" or baculae, which separate the costae from the endexine, is 
seen in figures 12 and 13 . The thin endexine and the continuous circular costa adjacent to the colpi are shown in figure 11. The tapering of the costae at the poles and their fusion at the extremities is displayed in figure 14. Affinity.-The marked tendency to split into thirds suggests the possibility of affinity to the Illiciaceae.

Occurrence.-Trisectoris costatus has been found in the Upper Cretaceous Coffee, McNairy, and Owl Creek Formations. A single specimen has been found just above the Cretaceous-Tertiary boundary in the Clayton Formation of Paleocene age.

Trisectoris stoveri n. sp.

Plate 8 , figure 1-6

Holotype.-11062-B, slide 2, coordinates $91.7 \times 4.6$, plate 8, figure 1 .

Paratype-D1322, slide 1, coordinates $95.9 \times 17.4$ (2 joined segments), plate 8 , figure 2 .

Paratype.-D1322, slide 1, coordinates $101.1 \times 14.3$ (one segment), plate 8 , figure 3 .

Diagnosis-Syncolpate pollen grains with prominent longitudinal costae; many costae interrupted or do not extend from pole to pole.

Description.-Pollen grains spherical or nearly so. On the basis of five complete specimens and 25 isolated segments (thirds), the diameter is determined to range from $41 \mu$ to $57 \mu$. Dimensions of isolated thirds range from $29 \mu$ to $52 \mu$ in polar dimension and $21 \mu$ to $51 \mu$ in equatorial dimension (average $40.8 \mu$ polar $\times 31.4 \mu$ equatorial). The number of costae at the equator ranges from 9 to 14. Some costae reach from pole to pole; others are interrupted. Costae are $2 \mu-5 \mu$ wide-widest about midway of their length and tapering slightly to their blunt ends. Costae adjacent to the colpi are continuous over the poles, thus forming a complete circle. Costae are subtended on their inner faces by \pm two rows of prominent baculae. Ektexine, including baculae, is $3 \mu-5 \mu$ thick; baculae are as much as $2 \mu$ long. The endexine is $1 \mu-2 \mu$ thick. This species differs from Trisectoris costatus by its slightly larger size and by the fact that many of the costae do not reach from pole to pole.

Discussion.-The interrupted nature of many of the costae is demonstrated particularly well in plate 8 , figures 2 and 3 . Figure 6 of plate 8 pictures an isolated third, which shows that the costa adjacent to the colpi passes over the pole without interruption, thus forming a complete circular costa. This species is named for Lewis E. Stover (1964), who first reported it as pollen type A from the Magothy Formation of Maryland. He indicated (written commun., 1969) that in his material the diameter of complete grains reaches $78 \mu$. This size is appreciably larger than that of specimens in my material from the same formation.
Affinity.-The marked tendency to split into thirds suggests the possibility of affinity to the Illiciaceae.

Occurrence.-Trisectoris stoveri has been found in the lower, middle, and upper parts of the Magothy Jormation of Late Cretaceous age. At present (1969), its range is limited to the Magothy.

Other Trisectoris species.-Two additional species that clearly belong to the genus Trisectoris were found. Only a few specimens were found; these were corsidered too few to provide adequate species circumscriptions, and consequently these species have not been named. They are included as additional records of the genus Trisectoris.

\section{Trisectoris sp. 1}

Plate 8, figures 7-9

Discussion.-No complete specimens were found, and only two isolated thirds serve to characterize this species. This species, with longitudinal costae and \pm two rows of prominent baculae which separate the costae from the endexine, clearly belongs to the genus Trisectoris. It differs from all other species by having prominent reticulate margos adjacent to the colpi. Plate 8, figure 7, shows this feature particularly well. Plate 8, figures 8 and 9, show that some of the costae do not reach from pole to pole; this condition approximates that observed in Trisectoris stoveri. Plate 8, figure 9, is an isolated segment cupped in the polar axis. The raticulate ornamentation is seen only at the pole and along the margo to the left. The dimensions of isolated segments are about the same as those of Trisectoris stoveri. (See plate descriptions.)

Affinity.-Possibly with the Illiciaceae.

Occurrence.-Only in the Amboy stoneware clar, of Kümmel and Knapp (1904) in the Magothy Formation of Late Cretaceous age.

\section{Trisectoris sp. 2}

Plate 8, figures 10-13

Discussion.-I did not find any complete specimens or a sufficient number of separate segments to justify formal naming of this species. The few specimens found in the uppermost Cretaceous sample of the Raton Formation from northern New Mexico have fewer, more robust costae and a slightly larger size range than $T$. costatus. T. sp. 2, on the basis of six separate "thirds," one "two-thirds," and about 20 broken fragments, is determined to have a size range of $26 \mu$ to $38 \mu$ (polar) and $37 \mu$ to $41 \mu$ (equatorial). One of the segments has nine costae, one has seven and the remainder have eight. This species has the same general morphology as Trisectoris costatus and clearly belongs to the genus. A photograph of two-thirds of a complete specimen is shown on plate 8, 
figure 10. One segment, which is contracted and cupped in the polar axis, is shown on plate 8 , figure 11. The type and arrangement of supporting baculae are shown on plate 8 , figures 12 and 13 . This species differs from $T$. costatus by possessing fewer, wider, and thicker costae and by being slightly larger.

Affinity.-Possibly with the Illiciaceae.

Occurrence.-To date (1969), this species has been found only in the uppermost Cretaceous part of the Raton Formation.

\section{MORPHOLOGIC SYNOPSIS OF THE GENERA ILLICIUM, TERSCISSUS, AND TRISECTORIS}

A summary of significant similarities and differences between the modern genus Illicium and the fossil genera Terscissus and Trisectoris can be expressed best in tabular form (table 1).

The presence of a median linear thickening of the colpal membrane is a morphologic character confined to species of the genus Illicium. The comparatively large size of species in the genus Terscissus (greater than $66 \mu$ ) serves to differentiate this genus from Illicium and Trisectoris; and the presence of prominent longitudinal costae with supporting baculae serves to separate the genus Trisectoris from the other two genera.

TABLE 1.-Comparison of some morphologic features of the genera Illicium, Terscissus, and Trisectoris

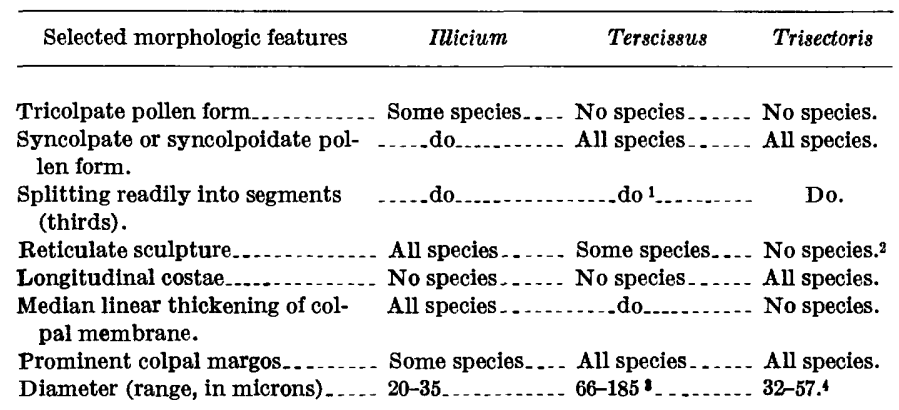

1 Except Terscissus sp. 1.

2 Trisectoris sp. 1 does not possess a reticulate surface sculpture but has a reticulate fringe on the colpal marges.

3 Minimum diameter of "thirds" of Terscissus sp. 2. Complete specimens of this species not found.

- Trisectoris stoveri reported as having a diameter as much as $78 \mu$ by L. E. Stover (written commun., 1969).

\section{OTHER POSSIBLY RELATED GENERA}

Many fossil pollen species possess morphological similarities to some species of I7licium; in particular, tricolpate reticulate species and "pseudosyncolpate" reticulate species show this similarity, because Illicium species are either tricolpate or syncolpate, and they have the reticulate surface sculpture. Howerer, modern tricolpate reticulate pollen is known from several other families such as the Ranunculaceae, Cruciferae, and Haloragaceae. Most reticulate syncolpate anf reticulate tricolpate fossil species cannot at present be referred with any degree of confidence to any of these extant families; consequently, they are placed provisionally in a form genus. The form genus erected by Elsik (in Stover and others, 1966) for pseudosyncolpate reticulate forms is Myocolpopollenites. Elsik's species $\boldsymbol{M}$. reticulatus was found in Mississippi embayment rocks.

\section{MYOCOLPOPOLLENITES}

Myocolpopollenites reticulatus Elsik, $19 ? 9$

Plate 9, figures 1-6

Discussion.-This genus and species of pollen is described in part as follows: "Marginate sexinous material extends past ends of colpi to poles where they join to form pseudosyncolpate triradiate crests" (Elsik, in Stover and others, 1966, p. 4). This species is included here for comparison with the species of Terscissus and Trisectoris, because Myocolpopollenites reticulatus is also found as isolated thirds. Separation crcurs along the colpi often enough that individual segments are common in our material. Interference contrast photographs of an equatorial view (pl. 9, figs. 3,4) show the character of the reticulum and the polar crests. An isolated segment (third) is shown on plate 9 , figures 5 and 6.

Affinity.-Elsik states that the affinity of this taxon is unknown. That this taxon has affinity with the Illiciaceae is not beyond the realm of possibility.

Occurrence.-Lower Eocene (Elsik, in Stover and others, 1966). Wilcox Group, lower Eocene, USGS sample localities D1846, D3574-B.

\section{TRICOLPITES}

Tricolpate reticulate species are commonly placed in the form genus Tricolpites. Three Tricolpites species are briefly discussed below :

Tricolpites sp. 1

Plate 9, figures 7-9

Discussion.-The colpi extend nearly to the poles and are bordered by very prominent margos. Some specimens occur as separated or isolated fragmerts, as shown on plate 9 , figure 9 . This feature is shared by the genera Illicium, Terscissus, and Trisectoris.

Occurrence.-This tricolpate species was found in the Eocene of Venezuela. 
Tricolpites sp. 2

Plate 9, figures 10, 11 and 14

Discussion.--This tricolpate reticulate species is slightly trilobed. The colpi extend almost to the poles and are bordered by fairly prominent margos. Figure 14 , plate 9 , shows the development of heavy margos to the extent that this specimen may represent a different species from that shown in figures 10 and 11. Sufficient specimens to clarify this possibility were unavailable. Occurrence.-McNairy Sand.

\section{Tricolpites sp. 3}

Plate 9, figures 12, 13

Discussion.-This tricolpate reticulate species is almost spherical but is smaller than the other pictured species of Tricolpites. It has colpi bordered by distinct margos. The colpi extend almost to the poles. The lacunae are distinctly larger than those seen in the other figured species of Tricolpites.

Occurrence.-McNairy Sand.

These few examples are included here merely to demonstrate some of the morphological variations found in fossil tricolpate and pseudosyncolpate pollen grains. Some of these morphological types may be related to the Illiciaceae, others probably have no relationship whatsoever. The genus Tricolpites undoubtedly accommodates species from several distinct families.

If the hypothesis of affinity of the genera Terscissus, Trisectoris, and possibly Myocolpopollenites to the Illiciaceae proves valid, then it will be evident from the number of new species belonging to these genera that have been found that this segment of the Ranales was undergoing rapid evolution in Late Cretaceous and early Paleocene time. It may be true, with the advent of a reticulate surface sculpture, as seen in Terscissus species $1-4$, that this character became fixed, and that the modern species of Illicium descended from this ancestral stock. Perhaps the nonreticulate genera and species, such as Terscissus grandis and Trisectoris, possessed fewer characteristics of survival value and thus became extinct.

\section{STRATIGRAPHIC DISTRIBUTION OF THE GENERA TERSCISSUS AND TRISECTORIS}

The species of Terscissus and Trisectoris mentioned in this report are all limited to the Late Cretaceous and Paleocene. The recognition of so many species of these hitherto unknown fossils does not necessarily mean that they have not been seen. Indeed, Stover (1964) figured a species of Trisectoris but did not give it a name. The lack of published palynological work, particularly from the Mississippi embayment area and from Venezuela, may partly explain this lack of reporting. Further, the fact that most specimens occur as isolated thirds delayed my recognition of them as pollen grains and may have deterred others from describing them.

The speciation demonstrated in the Late Cretaceous and early Tertiary certainly suggests that these genera originated in the Cretaceous and were eliminated frcm the floras or were evolutionarily modified by Eocene time. In Venezuela, literally thousands of samples frcm Eocene and Oligocene rocks have been examined, and none of these genera were seen. In the Mississippi embayment, hundreds of post-Paleocene samples have failed to yield any members of these genera. These facts are particularly striking in relation to the genus Terscissus. Species belonging to this genus are extremely lar ze for pollen grains and are not easily overlooked. Even species evolutionarily reduced to the size of modern Illicium, because of their distinctive morphology, would not be disregarded. Specimens of some of these genera, in limited parts of the section, are sufficiently numero's to indicate that their parent plants were significant elements of the fossil floras. The modern genus Illicium. a member of a primitive order of angiosperms, may have been derived from genera similar to the ones describad here. Although species of the genus Illicium are now living in the southern part of the United States, they are not numerous elements of the floras of the region. $T$. presence of modern Illicium in the area of the Miss'ssippi embayment suggests that the genus should be represented by fossil pollen in the same area. The fact that modern Illicium pollen has not been definitely recognized suggests that the plants were too few in number to produce sufficient pollen so that it would be likely to be found as fossils. The presence of a few plants in a region does not insure that these plants will produce enough pollen to provide a fossil record. It may be that after Paleocene time, the plants that producad pollen with an Illicium-, Terscissus-, or Trisectoris-like morphology were so reduced in number that they did not leave an as-yet-recognized fossil record. This record may eventually be found in species placed in the genus Tricolpites.

\section{THE GENUS TERSCISSUS}

Known ranges of species of Terscissus and Trisectoris are shown in figure 2. Terscissus grandis ranges from the upper part of the Upper Cretaceous McNairy Sant, through the Owl Creek Formation, and into the Palescene Clayton Formation. A slight variant, which cannot always be distinguished, may be limited to the $\mathrm{O}$ wl Creek Formation. A morphologically somewhat similar species Terscissus canalis has so far (1969) been fourd only in the uppermost Cretaceous Mito Juan Formation of western Venezuela. 


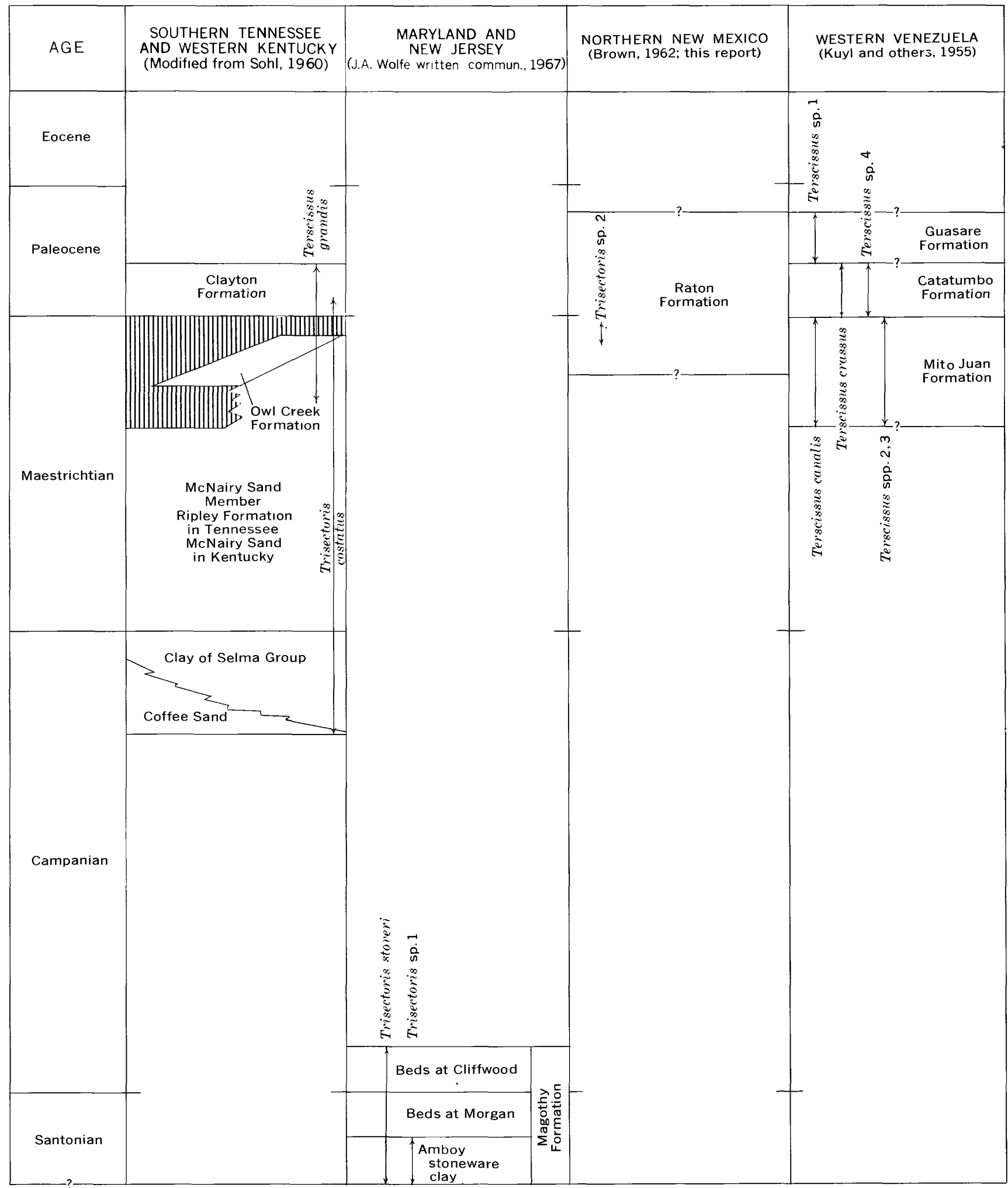

FigURE 2.-Stratigraphic ranges of species of the genera Terscissus and Trisectoris. 
A third species of Terscissus, T. crassus, is limited to the lower Paleocene Catatumbo Formation of western Venezuela. Morphologically, it is similar and probably closely related to the two previous species.

Several distinctly different species of Terscissus with reticulate surface sculpture were found in the Upper Cretaceous and lower Paleocene of Venezuela. A large species, Terscissus sp. 1, is confined to the Guasare Formation of Paleocene age. Another large reticulate species, Terscissus sp. 4, was found in the lower Paleocene Catatumbo Formation. Smaller reticulate species, Terscissus sp. 2 and Terscissus sp. 3, are limited to the Upper Cretaceous Mito Juan Formation of western Venezuela. These unnamed species particularly, owing to the fact that few specimens were recovered, may in the future be found to have slightly greater stratigraphic ranges.

\section{THE GENUS TRISECTORIS}

The geographic distribution of this genus, so far as known, is confined to rocks from the United States. Specimens of the type species Trisectoris costatus have been found in the Coffee Sand, the McNairy Sand, and the Owl Creek Formation, all of Late Cretaceous age, and in the Clayton Formation of Paleocene age. These formations are in the northern part of the Mississippi embayment area. The range extends from upper Campanian, through the Maestrichtian, and into the lower Paleocene. A very similar but distinct species, Trisectoris stoveri, is represented in the Magothy Formation of Santonian and basal Campanian age. No specimens of this genus have been found in rocks from the Santonian and lower Campanian of the Mississippi embayment, but then, comparatively few samples have as yet been examined from this interval.

Trisectoris sp. 1, differing from Trisectoris stoveri by possessing reticulate margos along the colpi, is found at present only in the Amboy stoneware clay of Kümmel and Knapp (1904), the basal clay of the Magothy Formation.

Another species, Trisectoris sp. 2, is present in the uppermost Cretaceous part of the Raton Formation of northern New Mexico. Brown (1962) placed at least the lower 50 feet of the Raton Formation in the Cretaceous, on the basis of finding the Upper Cretaceous plant Paleoaster inquirenda Knowlton at this level. More recent palynological work on a core which penetrated the Raton Formation in northern New Mexico reveals that the lower 265 feet of the Raton Formation is Cretaceous and that the remainder is Paleocene.
Trisectoris sp. 2 is not present in the Paleocene part, of the Raton Formation. Further work in this area may extend the range and provide enough additional specimens to permit description and naming of this species.

\section{REFERENCES CITED}

Andersen, H. V., 1960, Geology of Sabine Parish: Louiriana Geol. Survey Geol. Bull. 34, $164 \mathrm{p}$.

Brown, R. W., 1962, Paleocene flora of the Rocky Mountains and Great Plains : U.S. Geol. Survey Prof. Paper 375, 119 p.

Erdtman, Gunnar, 1943, An introduction to pollen anal-sis: Waltham, Mass., Chronica Botanica Co., 239 p., reprinted 1954.

1952, Angiosperms, in An introduction to palynology, v. 1 of Pollen morphology and plant taxonomy: Upraala, Sweden, Almqvist and Wiksell, $539 \mathrm{p}$.

Funkhouser, J. W., and Evitt, W. R., 2d, 1959, Preparrtion techniques for acid-insoluble microfossils : Micropalecntology, v. 5, no. 3, p. 369-379.

Kümmel, H. B., and Knapp, G. N., 1904, The stratigraphy of the New Jersey clays: New Jersey Geol. Soc. Final Rept. 6, p. 117-209.

Kuyl, O. S., Muller, J., and Waterbolk, H. Th., 1955, The Emplication of palynology to oil geology with reference to wertern Venezuela: Geologie en Mijnbouw, no. 3, new ser., r. 17, p. 49-76.

Pokrovskaia, I. M., 1950, Analyse pollinique: Bur. Recherches Géol., Géophys., et Minières, Service d'Information Géol., Annales, no. 24, $435 \mathrm{p}$.

Smith, A. C., 1947, The families Illiciaceae and Schizandraceae, No. 7 of Sargentia : Jamaica Plain, Mass., Arnold Arhoretum, 224 p.

Sohl, N. F., 1960, Archeogastropoda, Mesogastropoda and s'ratigraphy of the Ripley, Owl Creek, and Prairie Bluff Formations [Tennessee-Mississippi]: U.S. Geol. Survey Prof. Paper 331-A, 151 p. [1961].

Stebbins, G. L., 1950, Variation and evolution in plants: New York, Columbia Univ. Press, Biol. Ser. 16, 643 p.

Stover, L. E., 1964, Comparison of three Cretaceous spore-1Mllen assemblages from Maryland and England, in Palynolc sy in oil exploration-A symposium: Soc. Econ. Paleontologists and Mineralogists Spec. Pub. 11, p. 143-152.

Stover, L. E., Elsik, W. C., and Fairchild, W. W., 1966, New genera and species of early Tertiary palynomorphs from Gulf Coast: Kansas Univ. Paleont. Contributions Paper 5, p. 1-10.

Tschudy, R. H., 1966, Associated megaspores and microspores of the Cretaceous genus Ariadnaesporites Potonié, 1956, emend., in Geological Survey research $1966:$ : U.S. Geol. Survey Prof. Paper 550-D, p. D76-D82.

Wodehouse, R. P., 1935, Pollen grains, their structure, ilentification, and significance in science and medicine [1st ed.] : New York and London, McGraw-Hill Book Co., 574 p. 

PLATES 1-9 


\section{PLATE 1}

[All figures $\times 1,000$ ]

FIGURES 1-4. Illicium floridanum.

1. P2855, slide 1, coordinates $85.4 \times 9.4$, diameter $30 \mu$. Beginning of equatorial splitting.

2. P2855, slide 1, coordinates $81.6 \times 20.7$, diameter $31 \mu$. Beginning of polar splitting, high focus.

3. P2855, slide 1. Same specimen as fig. 2, low focus.

4. P2855, slide 2, coordinates $93.4 \times 12.6$. Separate segments, polar view.

5-8. Illicium henryi var. typicum.

5. P2857, slide 1 , coordinates $95.9 \times 14.5$, diameter $31 \mu$.

6. P2857, slide 1 , coordinates $93.6 \times 6.3$, diameter $32 \mu$.

7. P2857, slide 1, coordinates $82.7 \times 20.1$, diameter $33 \mu$. One segment disattached at one pole.

8. P2857, slide 1 , coordinates $87.4 \times 20.0$, diameter $30 \mu$. One segment completely disattached. 9-12. Illicium simonsii.

9. P2856, slide 1, coordinates $92.7 \times 7.6$, diameter $36 \mu$. Polar view of spherical grain.

10. P2856, slide 1, coordinates $84.3 \times 14.2$, flattened grain, diameter $40 \mu$. Note partially detached median linear thickening of furrow membrane.

11. P2856, slide 3, coordinates $98.5 \times 8.5$, partially flattened grain, diameter $40 \mu$. Note gradation in size of reticulum from pole to equator.

12. P2856, slide 1, coordinates $92.3 \times 14.5$, polar diameter $34 \mu$. Note large size of equatorial lacunae.

13-17. Illicium anisatum.

13. P3382, slide 3 , coordinates $80.3 \times 10.0$, diameter $33 \mu$, high focus.

14. Same specimen as fig. 13, low focus. Note median linear thickenings of furrow membrane.

15. P3382, slide 5, coordinates $102.1 \times 17.8$, segments detached at one pole.

16. P3382, slide 3 , coordinates $82.0 \times 10.2$, isolated segment in polar view.

17. P3382, slide 5. coordinates $111.5 \times 14.4$ isolated segment, equatorial view. 

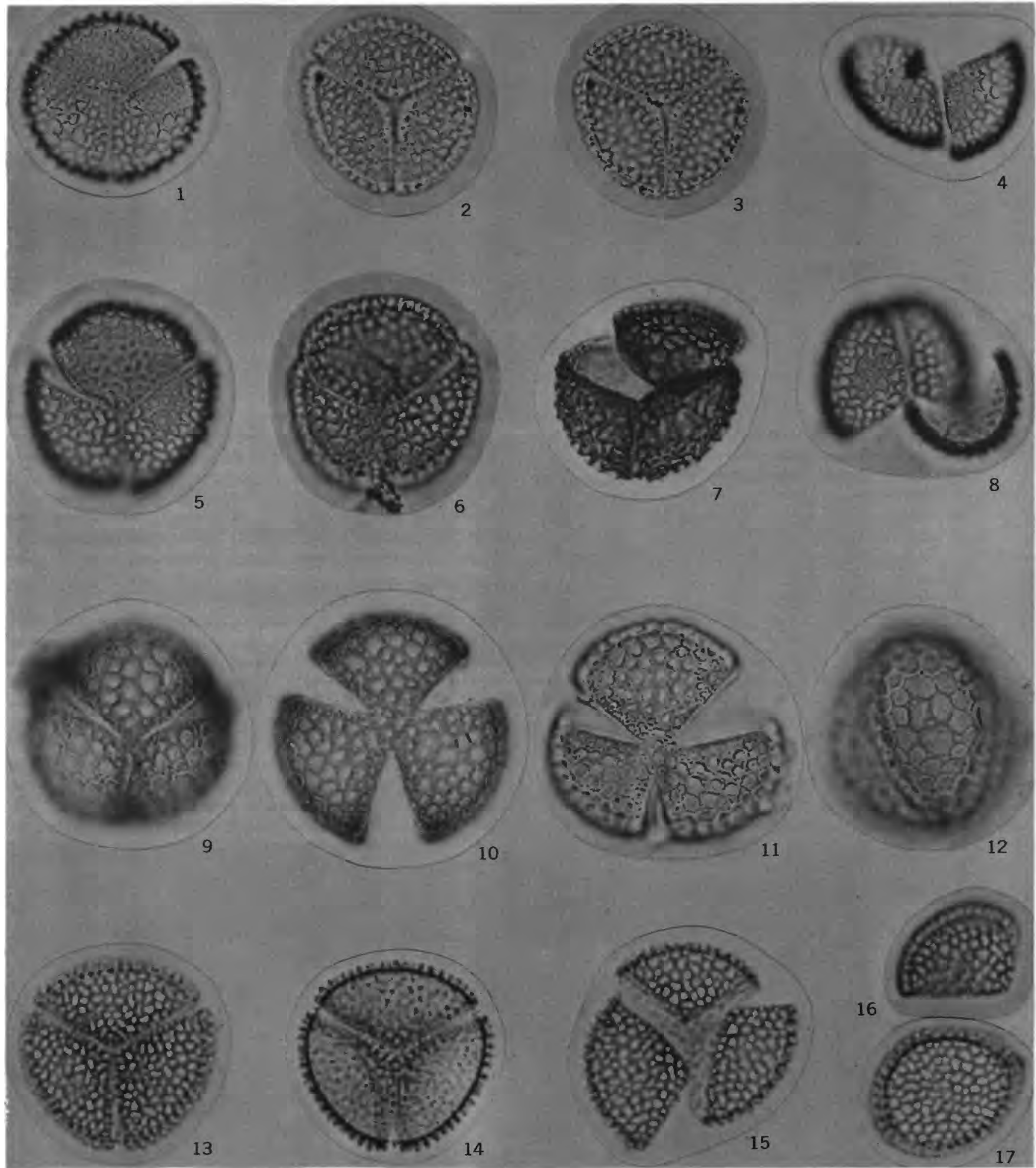

MODERN ILLICIUM SPECIES 


\section{PLATE 2}

\section{[All figures $\times$ 500]}

Figures 1-4. Terscissus grandis n. gen. and sp.

1. Holotype, USGS paleobotany loc. D3546-C, slide 5, coordinates $98.0 \times 11.5,176 \mu \times 182 \mu$.

2. Same specimen as fig. 1 but focussed on the margin to show detail of the baculae and thickening of endexine at colpi.

3. Paratype, USGS paleobotany loc. D3546-C, slide 5 , coordinates $88.3 \times 21.3,163 \mu \times 167 \mu$.

4. Paratype, USGS paleobotany loc. D1867, slide 8 , coordinates $91.3 \times 18.3,145 \mu \times 168 \mu$. The colpi can be seen extending completely around this specimen, dividing the spheroid into three segments. 


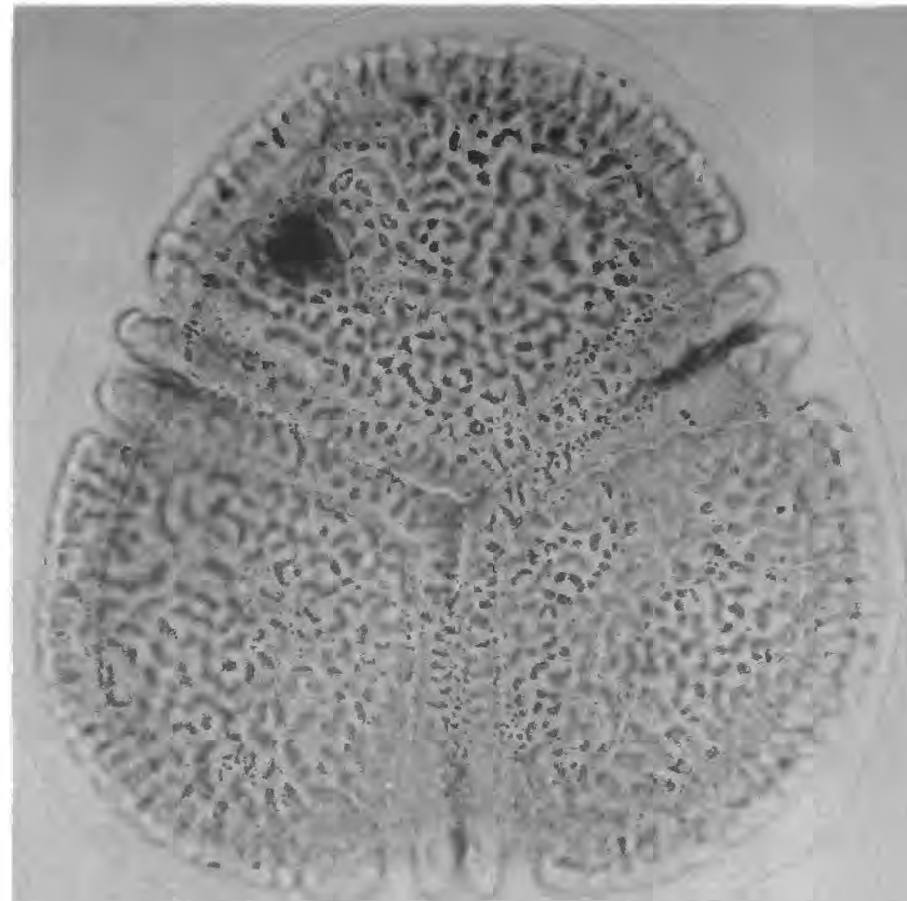

1

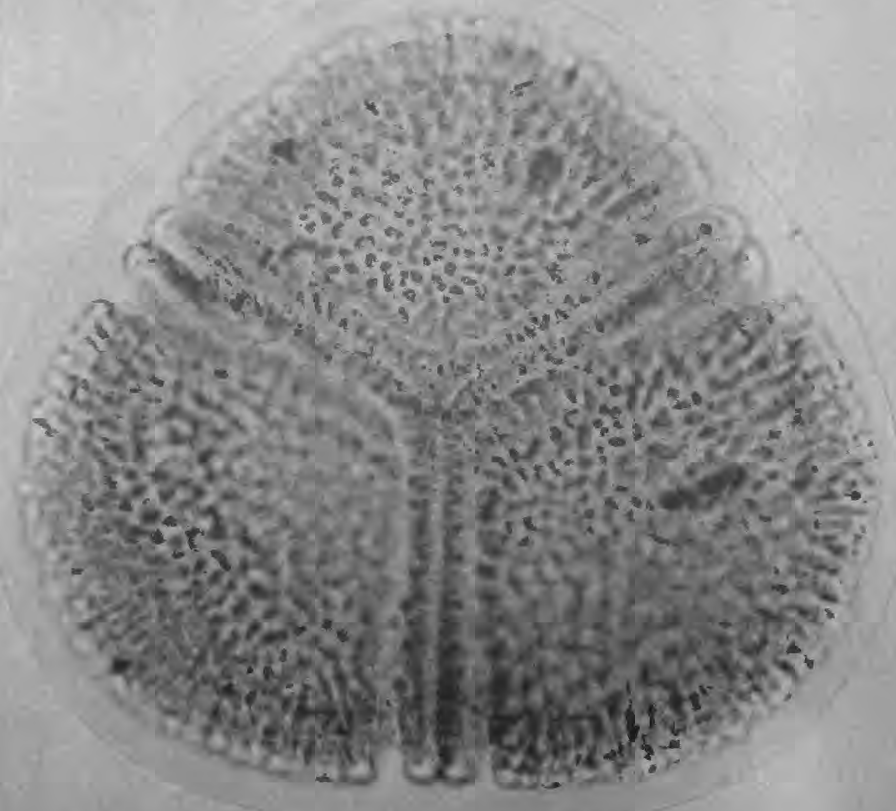

3

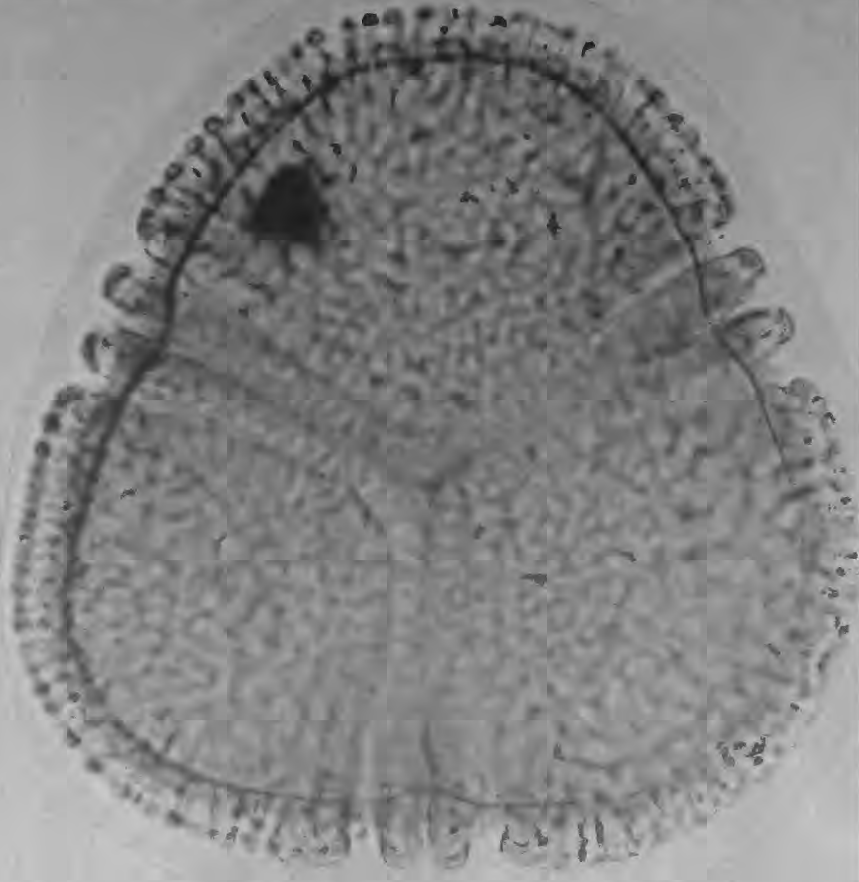

2

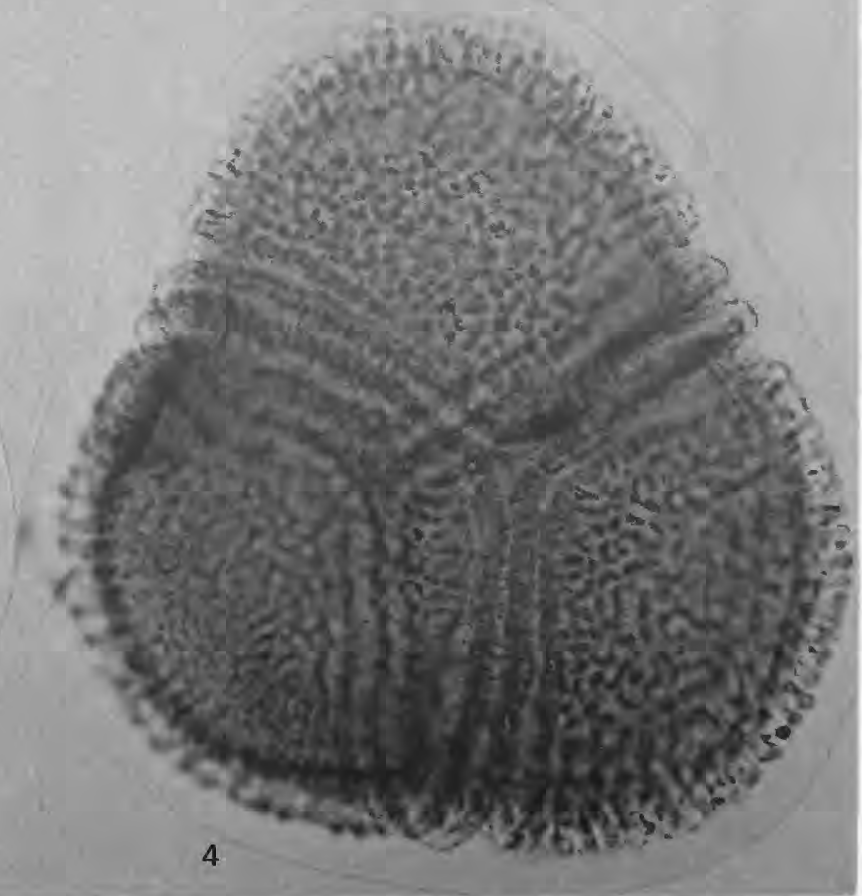

TERSCISSUS GRANDIS HOLOTYPE AND PARATYPES 


\section{PLATE 3}

[Figures 1 and $6 \times 1,000$; all others $\times 500$ ]

Figures 1-6. Terscissus grandis n. gen. and sp.

1. Segment of holotype photographed using interference contrast. Surface relief and verrucae between the larger surface elements are shown.

2. Isolated segment, USGS paleobotany loc. D1867, slide 8 , coordinates $101.4 \times 6.4,114 \mu \times 88 \mu$.

3. Isolated segment, USGS paleobotany loc. D1867, slide 8 , coordinates $113.2 \times 23.4,117 \mu \times 90 \mu$.

4. Isolated segment, USGS paleobotany loc. D3410-C, slide zeta, coordinates $79.2 \times 18.0,122 \mu \times 90 \mu$. Specimen from Owl Creek Formation showing slight tendency to form more than one channel parallel to the colpi.

5. Isolated segment, USGS paleobotany loc. D3410-C, slide gamma, coordinates $109.4 \times 3.5,122 \mu \times 109 \mu$. Specimen from Owl Creek Formation showing somewhat larger fused baculae and tendency to form additional incomplete channel.

6. Fragment of colpus margo, USGS paleobotany loc. D1867, slide 7, coordinates $104.7 \times 10.5$, thickness $12 \mu-18 \mu$. The upper end of the fragment shows the large baculae fused at the tips that form the margo. The fringelike material to the right is the torn endexine which is thicker at the margins of the colpi. 


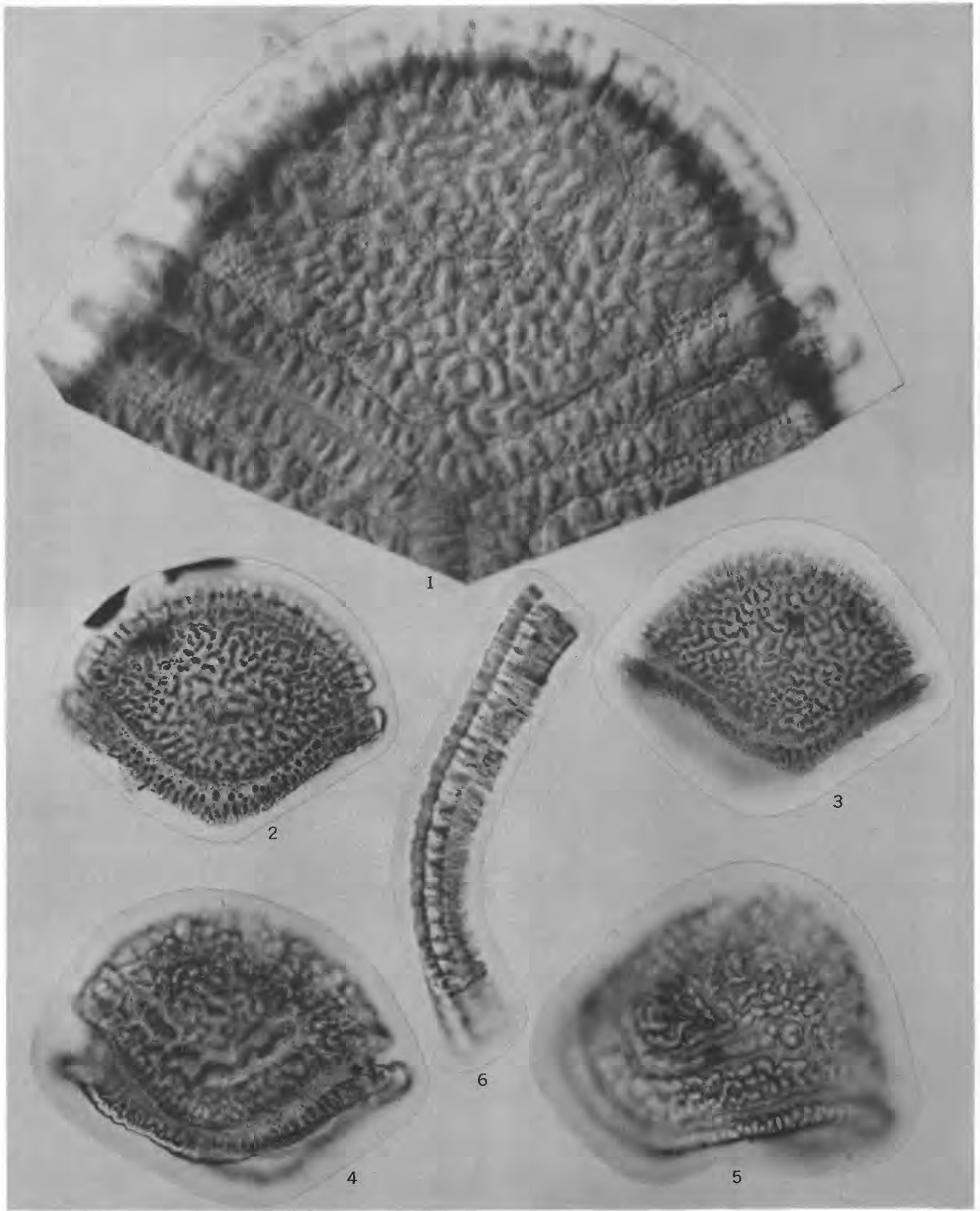

TERSCISSUS GRANDIS ISOLATED SEGMENTS 


\section{PLATE 4}

[Figures 1, 2, 3, 4 and $6 \times 500$; figure $5 \times 1,000]$

Figures 1-6. Terscissus canalis.

1. Holotype, RT-178V, slide alpha, coordinates $106.3 \times 7.9,140 \mu \times 184 \mu$. This is the only complete specimen.

2. Paratype, RT-178V, slide alpha, coordinates $95.0 \times 13.0,134 \mu \times 104 \mu$. Margo at lower left missing. Note round tipped clavae at apex.

3. Paratype, RT-178V, slide alpha, coordinates $107.0 \times 19.4,121 \mu \times 93 \mu$. Entire margo missing.

4. Paratype, RT-178V, slide beta, coordinates $97.2 \times 15.1$, segment, $101 \mu \times 146 \mu$.

5. Same specimen as fig. 4, photographed with interference contrast to show surface texture.

6. Fragment of colpus margo, TS-230, slide 6, coordinates $94.8 \times 7.7$. Cross section of wall showing fused clavae. Wall about $17 \mu$ thick; endexine about $5 \mu$ thick; ektexine, including clavae, about $12 \mu$ thick. 


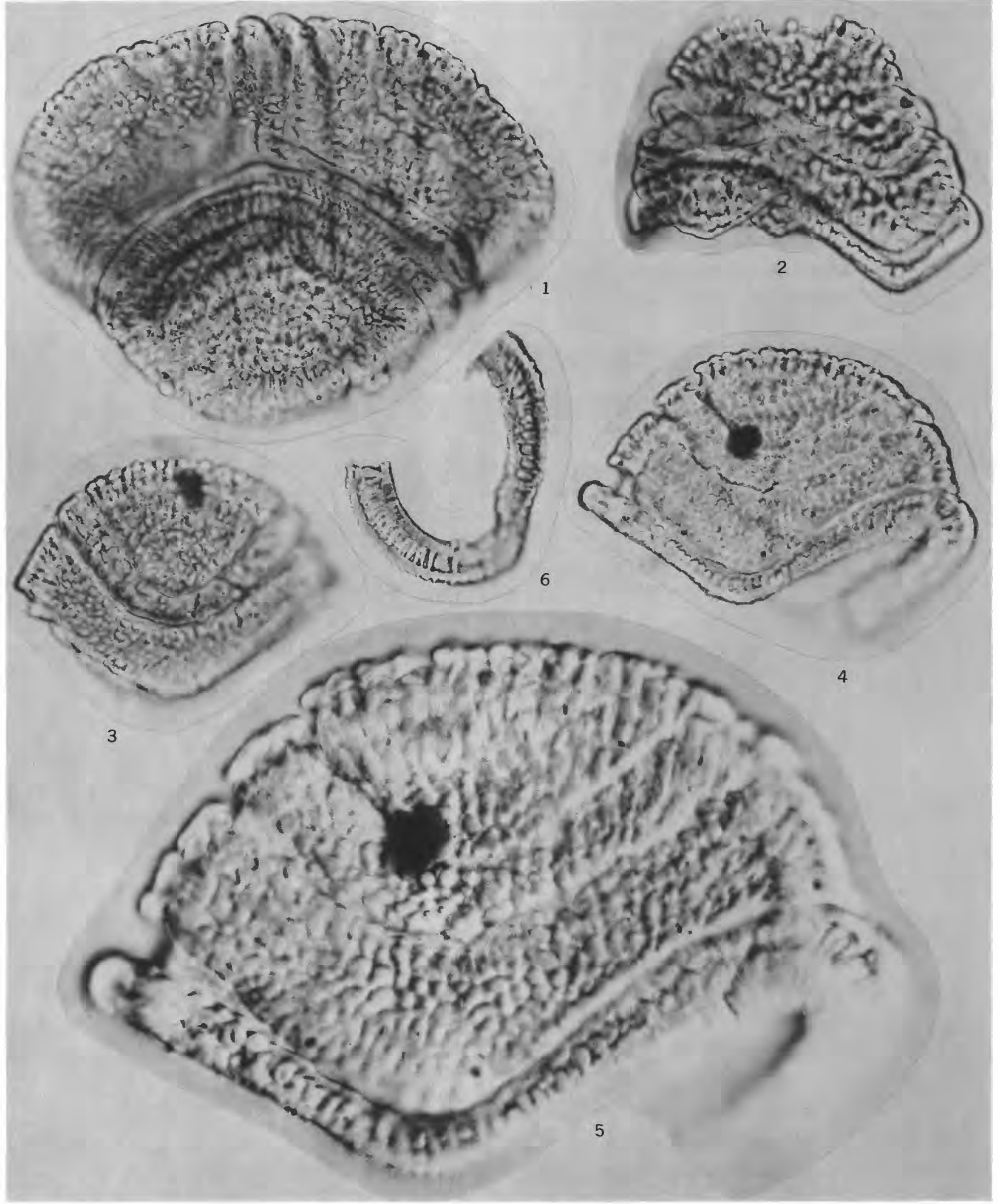




\section{PLATE 5}

[All figures $\times 500]$

Figures 1-6. Terscissus crassus.

1. Holotype, RT-179V, slide 6, coordinates $90.0 \times 16.9,106 \mu \times 186 \mu$. The holotype shows the remnants of the three sectors, even though torn and incomplete.

2. Paratype, RT-179V, slide 8 , coordinates $94.8 \times 13.7,98 \mu \times 140 \mu$.

3. Paratype, RT-179V, slide 10, coordinates $105.2 \times 19.3,101 \mu \times 150 \mu$. The narrow mushroom shape of the individual clavae is seen in the central part of the upper margin of the photograph.

4. Paratype, RT-179V, slide 10 , coordinates $88.4 \times 9.4,127 \mu \times 135 \mu$. Note fusion at tips of two coarse clavae at right margin of photograph.

5. Paratype, RT-179V, slide 9 (single grain preparation), coordinates $105.0 \times 12.0,96 \mu \times 138 \mu$. This specimen and the specimen shown on fig. 3 demonstrate the tendency of some grains to form ehannels parallel to the colpi.

6. RT-179V, slide 6, coordinates $102.3 \times 11.4,129 \mu \times 137 \mu$. This segment is flattened and viewed from inside. 


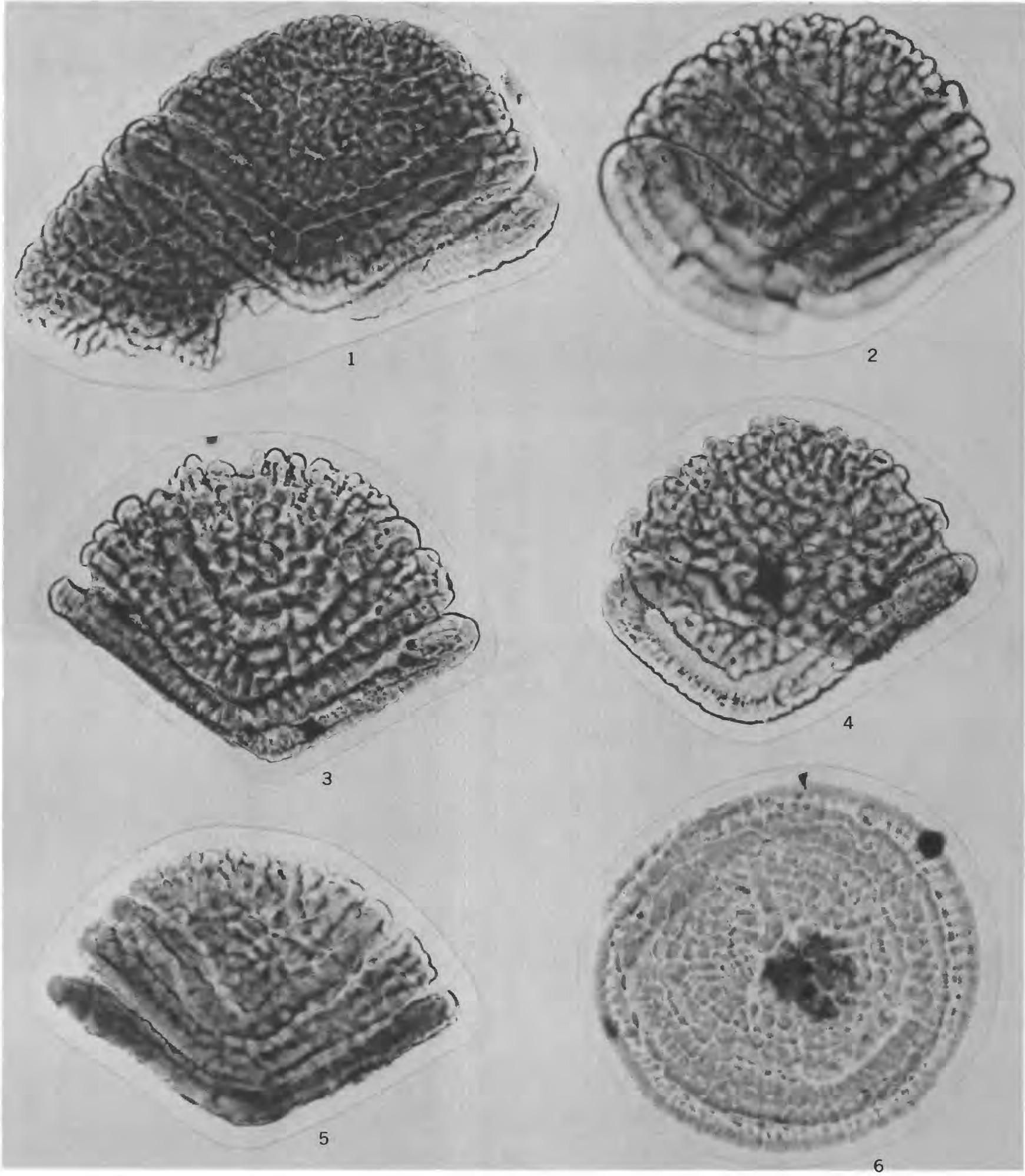

TERSCISSUS CRASSUS HOLOTYPE AND PARATYPES 


\section{PLATE 6}

\section{[All figures $\times$ 500]}

Figures 1, 2. Terscissus sp. 1.

1. RT-180V, slide 1 , coordinates $100.5 \times 9.0,180 \mu \times 184 \mu$. This is the only complete specimen of this species that was found. Note the pillarlike baculae supporting the reticulum (on left) and remnants of pillars on surface from which reticulum has been removed.

2. RT-180V, slide 2 , coordinates $86.0 \times 17.6,101 \mu \times 135 \mu$. The nature of the reticulum is well shown on this isolated segment.

3-6. Terscissus sp. 2.

3. TS-230, slide 11, coordinates $108.0 \times 11.7,77 \mu \times 98 \mu$. Equatorial view of a segment showing coarse reticulum.

4. Same specimen as fig. 3 . View of segment from the inside. Colpus margo with pillarlike baculae supporting reticulum is shown.

5. TS-230, slide 12 , coordinates $111.2 \times 12.8,59 \mu \times 104 \mu$. Segment showing coarse reticulum, low focus.

6. Same specimen as fig. 5 , high focus.

7-9. Terscissus sp. 3.

7. TS-200, slide 1 , coordinates $109.9 \times 22.9,66 \mu \times 74 \mu$. Cupped segment with fine reticulum.

8. TS-200, slide 4, coordinates $113.5 \times 8.3,68 \mu \times 76 \mu$. Lateral view of segment with fine reticulum, low focus.

9. Same specimen as fig. 8 , high focus. 


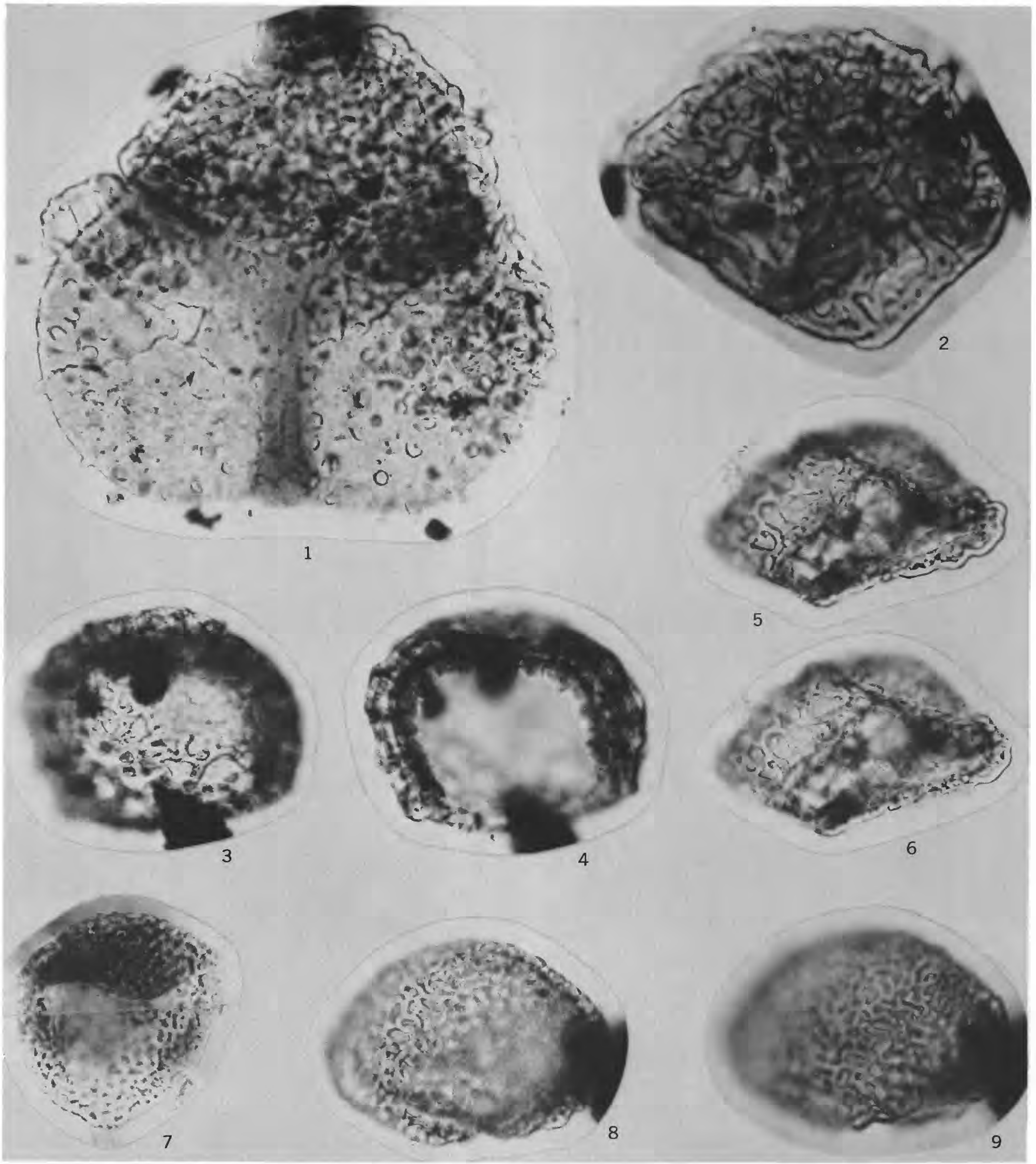

RETICULATE SPECIES OF TERSCISSUS 


\section{PLATE 7}

[Figures 1, $2 \times 500$; figures 3-11 and $14 \times 1,000$; figures 12 and $13 \times 1,500$ ] .

FrguRes 1, 2. Terscissus sp. 4 .

1. RT-179V, slide 13 (single grain preparation), coordinates $101.5 \times 10.8,163 \mu \times 166 \mu$.

2. Same specimen as fig. 1 , taken with a red Wratten $\mathbf{E}-22$ filter.

3-14. Trisectoris costatus $\mathrm{n}$. gen. and sp.

3. Holotype, USGS paleobotany loc. D3001, slide 1, coordinates $83.3 \times 7.6,37 \mu \times 39 \mu$.

4. Paratype, USGS palecbotany loc. D3001, slide 3 , coordinates $82.0 \times 20.7,31 \mu \times 34 \mu$.

5. Paratype, USGS paleobotany loc. D1867, slide 1, coordinates $96.5 \times 18.8,39 \mu \times 41 \mu$, high focus.

6. Same specimen as fig. 5 , low focus.

7. Paratype, USGS paleobotany loc. D1967-A, slide 2, coordinates $92.7 \times 2.4,29 \mu \times 33 \mu$, isolated segment (1/3), high focus.

8. Paratype, same specimen as fig. 7 , low focus.

9. Paratype, USGS paleobotany loc. D1864, slide 5, coordinates $76.4 \times 4.5,27 \mu \times 28 \mu$, isolated segment (1/3), high focus.

10. Same specimen as fig. 9 , median focus.

11. USGS paleobotany loc. D3001, slide 3 , coordinates $74.1 \times 20.6,25 \mu \times 31 \mu$. Segment showing circular rim adjacent to colpi and thin (torn) endexine.

12. USGS paleobotany loc. D3001, slide 1 , coordinates $83.1 \times 9.9,33 \mu$ long. Broken segment showing baculae between endexine and costae, low focus.

13. Same specimen as fig. 12 showing projecting baculae below the costae.

14. USGS paleobotany loc. D3001, slide 1 , coordinates $101.7 \times 5.3,20 \mu \times 29 \mu$. Segment (1/3) cupped in polar axis showing tapering of costae at the pole. 


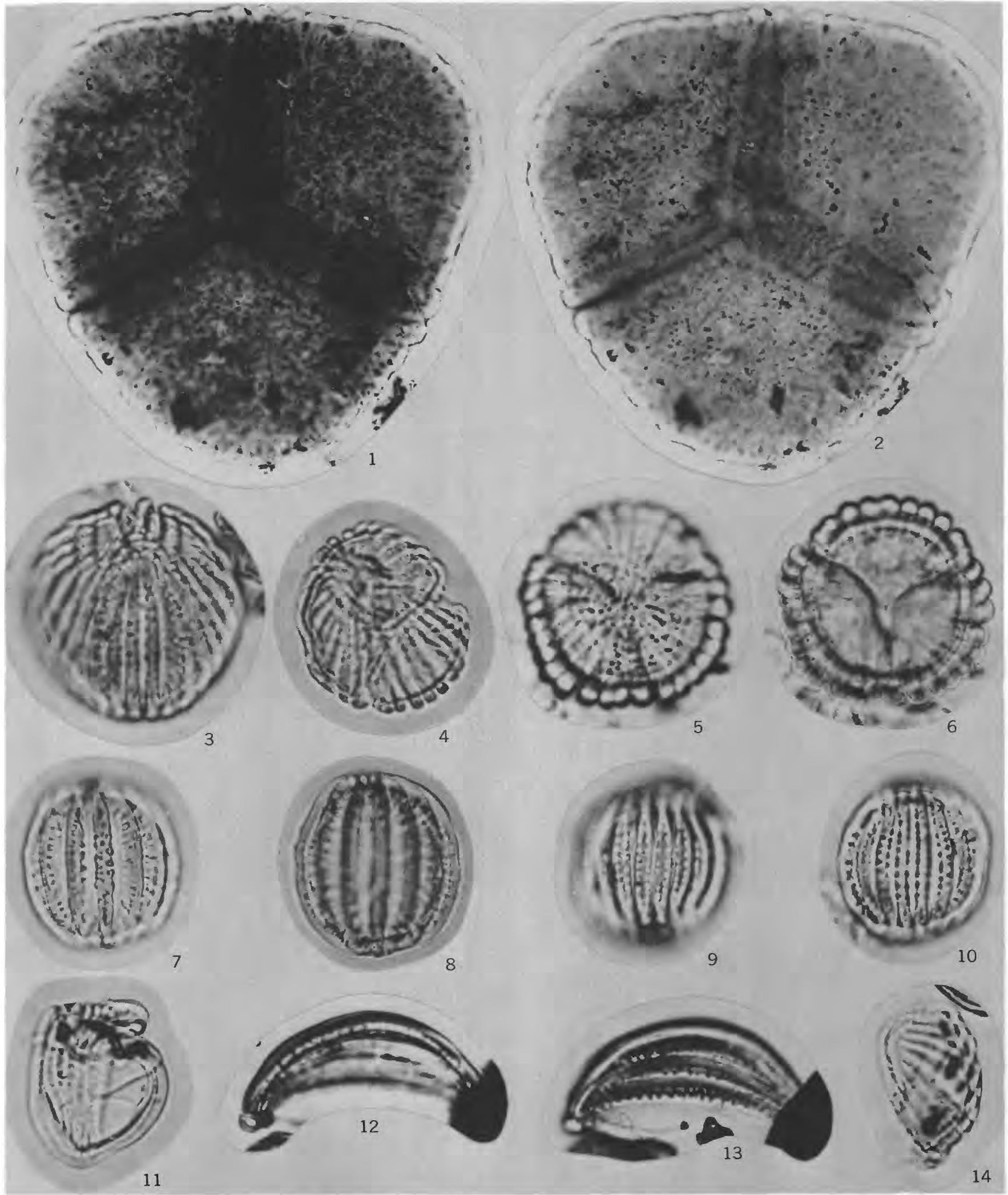

TERSCISSUS SPECIES 4 AND TRISECTORIS COSTATUS HOLOTYPE AND PARATYPES 


\section{PLATE 8}

[All figures $\times 1,000]$

FiguRes 1-6. Trisectoris stoveri.

1. Holotype, USGS paleobotany loc. $11062-B$, slide 2 , coordinates $91.7 \times 4.6,46 \mu \times 49 \mu$.

2. Paratype, USGS paleobotany loc. D1322, slide 1, coordinates $95.9 \times 17.4,41 \mu \times 47 \mu$. Two joined segments (2/3).

3. Paratype, USGS paleobotany loc. D1322, slide 1 , coordinates $101.1 \times 14.3,37 \mu \times 41 \mu$. One segment (1/3). In figs. 2 and 3 interrupted costae are seen.

4. USGS paleobotany loc. D1322, slide 3, coordinates $86.8 \times 19.4,33 \mu \times 49 \mu$, high focus.

5. Same specimen as fig. 4. Low focus showing annular ridge or costae adjacent to position of colpi.

6. USGS paleobotany loc. 11057 , slide 2 , coordinates $104.6 \times 14.7,29 \mu \times 33 \mu$.

7-9. Trisectoris sp. 1.

7. USGS paleobotany loc. 11056 , slide 1 , coordinates $85.2 \times 17.1,35 \mu \times 44 \mu$. Low focus of one segment (1/3). A species similar to $T$. stoveri but possessing a reticulate fringe along the colpi margins.

8. Same specimen as fig. 7, showing an interrupted costa and surface view of baculae.

9. USGS paleobotany loc. 11056, slide 1 , coordinates $79.9 \times 5.9,31 \mu \times 33 \mu$. One segment cupped in polar axis. Reticulate fringe on this specimen not nearly so prominent as that seen on fig. 7 .

10-13. Trisectoris sp. 2.

10. USGS paleobotany loc. D3910-C, slide 4, coordinates $79.9 \times 8.5,28 \mu \times 52 \mu$. Two segments $(2 / 3)$.

11. USGS paleobotany loc. D3910-C, slide 1 , coordinates $79.1 \times 20.8,33 \mu \times 34 \mu$. One segment cupped in the polar axis.

12. USGS paleobotany loc. D3910-C, slide 4, coordinates $110.0 \times 4.7,33 \mu \times 37 \mu$. Broken segment showing baculae below coarse costae.

13. USGS paleobotany loc. D3910-C, slide 1 , coordinates $78.2 \times 3.6,28 \mu \times 41 \mu$. Distorted segment $(1 / 3)$ showing annular costa adjacent to colpi and baculae suspended from costae. 


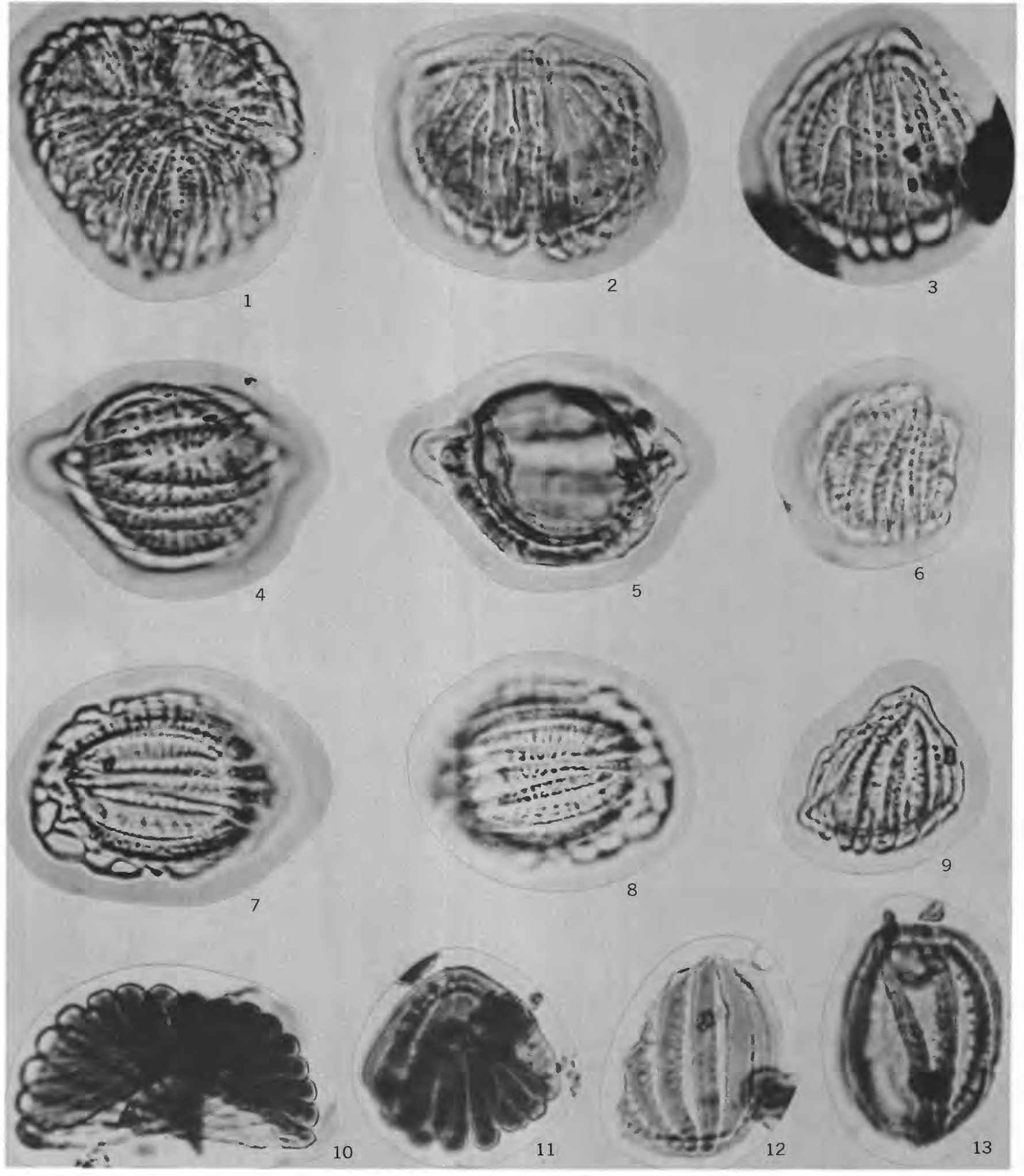

TRISECTORIS STOVERI HOLOTYPE AND PARATYPES AND OTHER SPECIES OF TRISECTORIS 


\section{PLATE 9}

[All figures $\times 1,000]$

Figures 1-6. Myocolpopollenites reticulatus Elsik.

1. USGS paleobotany loc. D1846, slide 9 , coordinates $80.7 \times 20.7,54 \mu \times 44 \mu$, equatorial view.

2. USGS paleobotany loc. D1846, slide 6, coordinates $91.4 \times 6.7$, diameter $49 \mu$, polar view.

3. USGS paleobotany loc. D1846, slide 10 , coordinates $86.6 \times 18.8,39 \mu \times 49 \mu$. Photographed with interference contrast to show reticulum relief.

4. USGS paleobotany loc. D3574-B, slide 2, coordinates $90.4 \times 7.1,43 \mu \times 41 \mu$. Interference contrast showing reticulum and margin of colpus.

5. USGS paleobotany loc. D1846, slide 11 , coordinates $93.7 \times 17.7,34 \mu \times 38 \mu$. Segment (1/3), equatorial view.

6. Same specimen as fig. 5 . View from inside showing thickness of wall including reticulum.

7-9. Tricolpites sp. 1.

7. Z-390V slide, coordinates $92.0 \times 16.8,32 \mu \times 33 \mu$.

8. Z-390V slide, coordinates $98.5 \times 8.7,43 \mu \times 27 \mu$. Two joined segments (2/3).

9. Z-390V slide, coordinates $95.8 \times 1.5,17 \mu \times 20 \mu$. Isolated segment (1/3).

10, 11, 14. Tricolpites sp. 2.

10. USGS paleobotany loc. D3000, slide T4, coordinates $86.2 \times 8.2,43 \mu \times 46 \mu$.

11. USGS paleobotany loc. D3000, slide T2, coordinates $91.1 \times 12.2,39 \mu \times 41 \mu$. Showing open colpi and margos.

14. USGS paleobotany loc. D3000, slide T5, coordinates $106.9 \times 16.3,36 \mu \times 41 \mu$. Note heavy margos.

12, 13. Tricolpites sp. 3.

12. USGS paleobotany loc. D3000, slide T2, coordinates $94.6 \times 11.9$, diameter $26 \mu$.

13. Same specimen as fig. 12. 


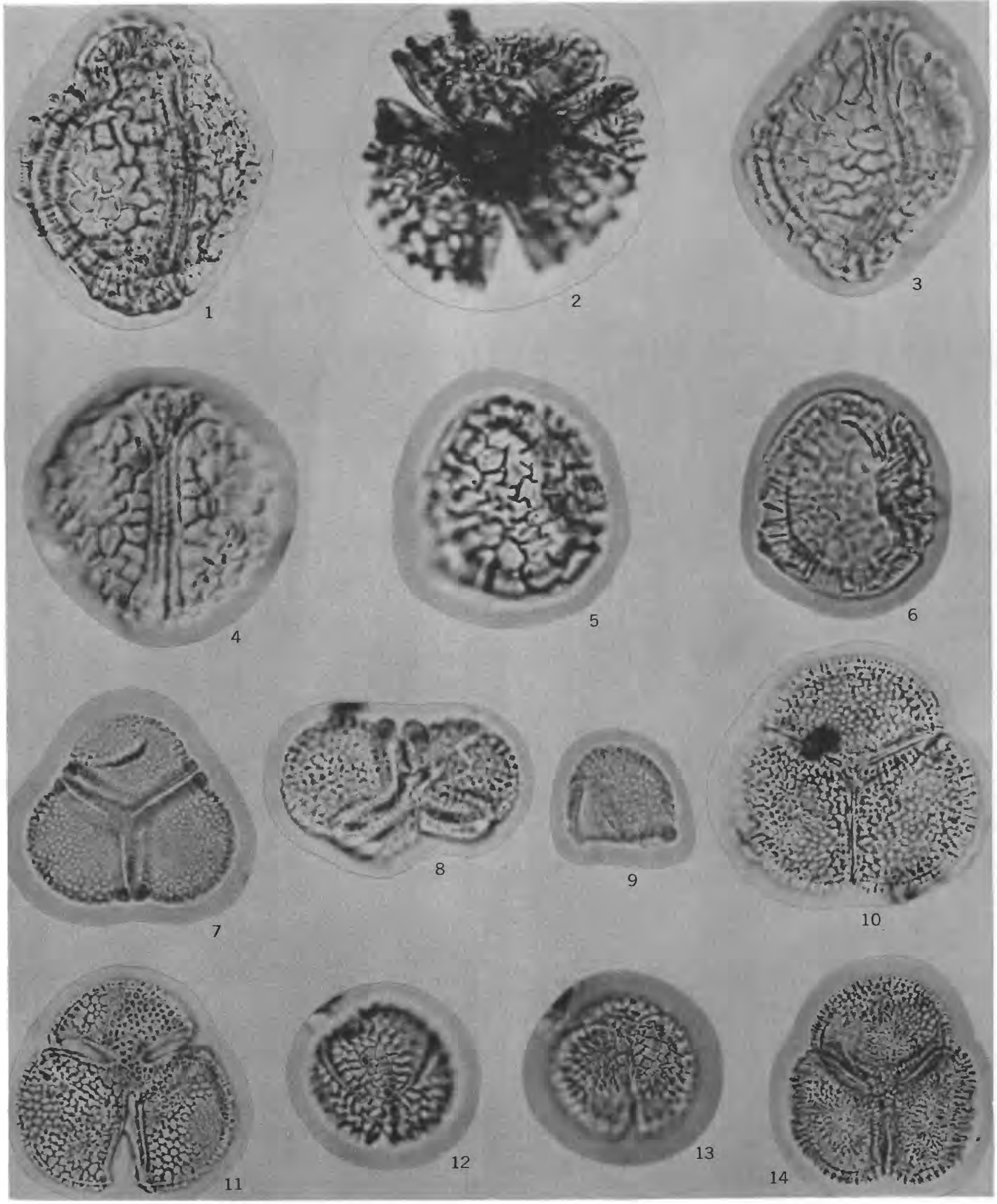

